\title{
Sludge dewatering in a decanter centrifuge aided by cationic flocculant Praestol 855BS and essential oil of waste orange peels
}

\author{
Anna Kowalczyk*, Tadeusz Piecuch \\ Koszalin University of Technology, Poland \\ Faculty of Civil Engineering, Environmental and Geodetic Sciences \\ *Corresponding author's e-mail: anna.kowalczyk@tu.koszalin.pl
}

Keywords: flocculant, essential oils, sewage sludge, odours, noxious odour.

\begin{abstract}
In the study the comparative analysis of test results of drainage of municipal wastewater sludge was conducted with the use of flocculant Praestol 855BS and the mixture of flocculant Praestol 855BS 50\% + orange essential oil $50 \%$, as the reagents supporting this process. It was also attempted to reduce unpleasant smells exuding from the drained sludge.

The process of drainage of municipal wastewater sludge was conducted in the laboratory setting centrifuge of MPW-350 type. The variable independent parameters were centrifugation time, centrifugation speed, dosage of flocculant Praestol 855BS as well as dosage of mixture in the proportion of flocculant Praestol 855BS (50\%) + orange essential oil (50\%). The following parameters were subject to assessment: water content in the sludge, dry mass content in the reflux as well as time of maintenance of the oil's smell in the sludge. The conducted tests demonstrated that the orange essential oil has an impact on drop in resultant quality parameters of the drainage process of municipal wastewater sludge. Batching of the orange essential oil has an impact on considerable reduction of odours exuding from drained wastewater sludge, and thus on improvement of work conditions connected with operation of centrifugal separators. Bearing in mind both the efficient drainage process of wastewater sludge as well as simultaneous reduction of unpleasant smells exuding from the sludge during this process it is assumed and recommended to simultaneously apply both reagents, that is flocculant Praestol 855BS (50\%) and orange essential oil, also in the volume of $50 \%$.
\end{abstract}

\section{Introduction}

Odours constitute air pollution which causes discomfort in the reception of external environment. Currently these are one of the most frequent sources of nuisance in the surrounding (Kujawa-Roeleveld and Michałkiewicz 2011).

Odour nuisance as well as methods of its elimination are more and more frequently becoming the object of research of many institutions, including Szczecin University of Technology (Kośmider and Krajewska 2007, Kośmider 1994, Kośmider 2007, Kośmider et al. 2012), Lublin University of Technology (Czerwiński and Ozonek 2008, Ozonek et al. 2009, Ozonek et al. 2009), Łódź University of Technology (Szynkowska et al. 2009, Szynkowska et al. 2008), Wrocław University of Technology (Sówka 2011, Sówka et al. 2013, Sówka et al. 2011, Szklarczyk et al. 2010), Warsaw University of Technology (Kulig 2005, Kulig et al. 2010), University of Warmia and Mazury in Olsztyn (Brudniak et al. 2013, Brudniak et al. 2014, Dębowski et al. 2008) as well as Koszalin University of Technology (Kowalczyk and Piecuch 2011, Kowalczyk et al. 2010, Kowalczyk et al. 2013, Piecuch et al. 2015, Piecuch et al. 2011).
The Department of Water and Silt Technology as well as Waste Disposal of Koszalin University of Technology has been conducting research concerning reduction of odour nuisance for many years. The masking method, which consists in replacement of undesired smell with more pleasant one, is used for odour elimination. Natural essential oils obtained from fresh plant materials in the process of distillation with water vapour are used as masking agents. The aromatic extracts are sprayed with the use of sprinklers or batched directly to the wastewater sludge before the process of drainage in the centrifugal separators.

The objective of this study is the comparative assessment of test results connected with drainage of municipal wastewater sludge with the use of flocculant Praestol 855BS as well as the mixture of $50 \%$ of flocculant Praestol $855 \mathrm{BS}+50 \%$ of orange essential oil as the reagents supporting this process as well as reduction of odour nuisance connected with drained sediments.

\section{Test Method}

\section{Drainage of municipal wastewater sludge}

The process of drainage of municipal wastewater sludge was conducted in the laboratory setting centrifuge of MPW-350 type. 
The activated sludge, stabilised as a result of methane fermentation, was used as the feed for mechanical drainage process. It collected from Jamno Sewage Treatment Plant directly from the pressure conduit feeding sediment from the separated open sludge digestion chamber to decantation centrifuges and stabilised as a result of methane fermentation. The fixed values of the drainage process were the parameters characterising the feed, i.e.: $\mathrm{pH}[-]$, temperature $\left[{ }^{\circ} \mathrm{C}\right]$, colour, structure, smell, water content $\mathrm{W}_{\mathrm{N}}[\%]$ as well as the content of dry mass $\beta_{\mathrm{N}}\left[\mathrm{mg} / \mathrm{dm}^{3}\right]$.

Variable parameters, independent of drainage process:

- $\mathrm{x}_{1}$ - centrifugation time $\mathrm{t}$ [minutes]: $\mathrm{t}_{1}=1$ min., $\mathrm{t}_{2}=2 \mathrm{~min}$., $\mathrm{t}_{3}=5$ min., $\mathrm{t}_{4}=8$ min., $\mathrm{t}_{5}=10 \mathrm{~min}$;

- $\mathrm{x}_{2}-$ centrifugation speed $\mathrm{n}$ [rotations/minute]: $\mathrm{n}_{1}=$ 1000 rotations/minute, $\mathrm{n}_{2}=1500$ rotations/minute, $\mathrm{n}_{3}=2000$ rotations $/$ minute, $\mathrm{n}_{4}=2500$ rotations $/$ minute, $\mathrm{n}_{5}=3000$ rotations/minute;

- $\mathrm{x}_{3}$ - batch of flocculant Praestol 855BS $\mathrm{C}_{\mathrm{F}}\left[\mathrm{ml} / \mathrm{dm}^{3}\right]$ : $\mathrm{C}_{\mathrm{F} 0}=0 \mathrm{ml} / \mathrm{dm}^{3}, \mathrm{C}_{\mathrm{F} 1}=18 \mathrm{ml} / \mathrm{dm}^{3}, \mathrm{C}_{\mathrm{F} 2}=23 \mathrm{ml} / \mathrm{dm}^{3}, \mathrm{C}_{\mathrm{F} 3}$ $=28 \mathrm{ml} / \mathrm{dm}^{3}, \mathrm{C}_{\mathrm{F} 4}=33 \mathrm{ml} / \mathrm{dm}^{3}, \mathrm{C}_{\mathrm{F} 5}=38 \mathrm{ml} / \mathrm{dm}^{3}, \mathrm{C}_{\mathrm{F} 6}=$ $48 \mathrm{ml} / \mathrm{dm}^{3}$;

- $\mathrm{x}_{4}$ - batch of mixture in the proportion of flocculant Praestol 855BS (50\%) + orange essential oil $(50 \%)$ $\mathrm{C}_{\mathrm{F} / \mathrm{O}}\left[\mathrm{ml} / \mathrm{dm}^{3}\right]: \mathrm{C}_{\mathrm{F} / \mathrm{O} 0}=0 \mathrm{ml} / \mathrm{dm}^{3}, \mathrm{C}_{\mathrm{F} / \mathrm{O} 1}=18 \mathrm{ml} / \mathrm{dm}^{3}$, $\mathrm{C}_{\mathrm{F} / \mathrm{O} 2}=23 \mathrm{ml} / \mathrm{dm}^{3}, \mathrm{C}_{\mathrm{F} / \mathrm{O} 3}=28 \mathrm{ml} / \mathrm{dm}^{3}, \mathrm{C}_{\mathrm{F} / \mathrm{O} 4}=33 \mathrm{ml} / \mathrm{dm}^{3}$, $\mathrm{C}_{\mathrm{F} / \mathrm{O} 5}=38 \mathrm{ml} / \mathrm{dm}^{3}, \mathrm{C}_{\mathrm{F} / \mathrm{O} 6}=48 \mathrm{ml} / \mathrm{dm}^{3}$.

Dependent (resultant) variable parameters of the drainage process:

- $\mathrm{y}_{1}-$ content of water in the sediment $\mathrm{W}[\%]$,

- $\mathrm{y}_{2}-$ content of dry mass in the reflux $\beta\left[\mathrm{mg} / \mathrm{dm}^{3}\right]$,

- $y_{3}$ - time of maintenance of smell in the sediment $\mathrm{T}$ [minutes].

Laboratory tests of drainage of municipal wastewater sludge consisted of two series:

Series I - Drainage of municipal wastewater sludge with the use of flocculant Praestol 855BS.

Series II - Drainage of municipal wastewater sludge with the use of mixture of flocculant Praestol 855BS (50\%) + orange oil $(50 \%)$.

In the first series, the first stage of tests was conducted at fixed centrifugation speed $n$ equalling 2500 rotations/minute as well as fixed batch of the added flocculant solution with the concentration of $0.3 \%$, which amounted to $28 \mathrm{ml} / \mathrm{dm}^{3}$. The centrifugation time $\left(\mathrm{x}_{1}\right)$, which changed from 1 to 10 minutes, was a variable parameter. The second stage of tests was conducted with fixed value of parameter $\mathrm{x}_{1}$ (centrifugation time) amounting to 2 minutes (central approximation point), fixed batch of flocculant solution $\left(\mathrm{x}_{3}\right)$ amounting to $28 \mathrm{ml} / \mathrm{dm}^{3}$ at variable value of independent parameter $\mathrm{x}_{2}-$ centrifugation speed within the range from 1000 to 3000 rotations/minute. In the third stage of tests, the fixed independent parameters were: centrifugation time $\mathrm{t}$ amounting to 2 minutes and centrifugation speed n, which amounted to 2500 rotations/ /minute. The variable parameter was a dosage of batched flocculant solution with the concentration of $0.3 \%$ within the range from 0 to $48 \mathrm{ml} / \mathrm{dm}^{3}$.

In the second series, the first stage of tests was conducted at fixed centrifugation speed $\mathrm{n}$ amounting to 2500 rotations/ /minute and fixed dosage of added mixture of flocculant Praestol $855 \mathrm{BS}(50 \%)+$ orange oil $(50 \%)$, which amounted to $28 \mathrm{ml} / \mathrm{dm}^{3}$. The variable parameter was centrifugation time $\left(\mathrm{x}_{1}\right)$, which varied from 1 to 10 minutes. The second stage of tests was conducted with fixed value of parameter $\mathrm{x}_{1}$ (centrifugation time) amounting to two minutes (central approximation point), fixed dosage of mixture of flocculant Praestol 855BS (50\%) + orange oil $(50 \%)\left(\mathrm{x}_{4}\right)$ amounting to $28 \mathrm{ml} / \mathrm{dm}^{3}$ with variable value of independent parameter $\mathrm{x}_{2}-$ centrifugation speed within the range from 1000 to 3000 rotations/minute. In the third stage of tests, the independent fixed parameters were: centrifugation time $\mathrm{t}$ amounting to two minutes and centrifugation speed $\mathrm{n}$, which amounted to 2500 rotations/minute. The variable parameter was a dosage of batched mixture of flocculant Praestol 855BS (50\%) + orange oil $(50 \%)$ within the range from 0 to $48 \mathrm{ml} / \mathrm{dm}^{3}$.

\section{Measurement of smell}

The time of maintenance of neutralized smell of the sediment was determined organoleptically by measuring the time of maintaining the smell of orange essential oil. The organoleptic assessment was conducted by a team consisting of four persons. Each person had a card on which he/she recorded the results. The results obtained from all persons gave a result which was used to determine the time of neutralization of odours in the centrifuged sediment.

\section{Characteristics of wastewater sludge}

The wastewater sludge with the following parameters was used for tests:

- $\mathrm{pH}: 7.55$;

- temperature: $20^{\circ} \mathrm{C}$;

- colour: black;

- sludge structure: uniform, slowly settling, in a form of suspension;

- smell: putrid;

- content of water $\mathrm{W}_{\mathrm{N}}: 97.7 \%$;

- content of dry mass $\beta_{\mathrm{N}}: 21180 \mathrm{mg} / \mathrm{dm}^{3}$.

\section{Characteristics of cationic flocculant PRAESTOL 855BS}

The drainage process in the laboratory setting centrifuge of MPW-350 type was supported with cationic flocculant with trade name Praestol 855BS, which is used in Jamno Sewage Treatment Plant. The experimentally selected and used dosage of the flocculant in the sewage treatment plant amounts to $3.68 \mathrm{~kg} / \mathrm{Mg}$ of dry organic mass. The sludge drained to the level of $68-75 \%$ water content is obtained during drainage.

Table 1 includes the information on basic physical and chemical properties of flocculant Praestol 855BS used for tests.

\section{Characteristics of orange essential oil}

Natural orange essential oil manufactured from orange peels in the process of distillation with water vapour was used for testing the process of mechanical drainage of municipal wastewater sludge in the laboratory.

Table 2 includes information on basic physical and chemical properties of orange essential oil used for tests.

The orange oil contains mainly neroli and limonene.

\section{Results}

Table 3 and Figure 1 include tests results of the impact of centrifugation time $\mathrm{t}[\mathrm{min}]$ on the water content in the sludge $\mathrm{W}[\%]$. 
Table 1. Characteristics of flocculant Praestol 855BS (ASHLAND)

\begin{tabular}{|c|c|}
\hline Appearance & Granulated, solid \\
\hline Colour & $\begin{array}{c}\text { white } \\
\text { light yellow }\end{array}$ \\
\hline Smell & amine \\
\hline Smell threshold & no available data \\
\hline Ignition temperature & not applicable \\
\hline Vaporization speed & no available data \\
\hline $\begin{array}{l}\text { Spontaneous ignition } \\
\text { temperature }\end{array}$ & no available data \\
\hline Lower explosive limit & $30.000 \mathrm{mg} / \mathrm{dm}^{3}$ \\
\hline Upper explosive limit & no available data \\
\hline Flammability (of solid, gas) & no available data \\
\hline Oxidizing properties & no available data \\
\hline Flammability number & no available data \\
\hline Molecular weight & no available data \\
\hline $\mathrm{pH}$ & 7 concentration $10,00 \mathrm{~g} / \mathrm{l}$ \\
\hline Melting point & not applicable \\
\hline Boiling point & not applicable \\
\hline Sublimation temperature & no available data \\
\hline Vapour pressure & $<0,02 \mathrm{hPa}$ \\
\hline Density & about $0,72 \mathrm{~g} / \mathrm{cm}^{3}$ \\
\hline Relative density & no available data \\
\hline Water solubility & slightly soluble \\
\hline $\begin{array}{l}\text { Distribution ratio: } \\
\text { noctanol/water }\end{array}$ & no available data \\
\hline Solubility in other solvents & no available data \\
\hline Thermal decomposition & $>150^{\circ} \mathrm{C}$ \\
\hline Absolute viscosity & no available data \\
\hline Kinematic viscosity & no available data \\
\hline Outflow time & no available data \\
\hline Resistance to shock & no available data \\
\hline Relative density of vapours & no available data \\
\hline Surface tension & no available data \\
\hline Conductivity & no available data \\
\hline Oxidation potential & no available data \\
\hline Refractive index & no available data \\
\hline Glow temperature & no available data \\
\hline Bulk density & $600 \mathrm{~kg} / \mathrm{m}^{3}$ \\
\hline Outflow time & no available data \\
\hline
\end{tabular}

Table 2. Characteristics of orange essential oil

\begin{tabular}{|l|c|}
\hline Appearance & Liquid \\
\hline Colour & Yellow \\
\hline Smell & Orange \\
\hline Density $\mathrm{d}_{20}{ }^{20}$ & $0.850 \mathrm{~g} / \mathrm{cm}^{3}$ \\
\hline Refractive index $\mathrm{n}_{\mathrm{D}}{ }^{20}$ & 1.473 \\
\hline
\end{tabular}


Table 4 and Figure 2 include test results of the impact of centrifugation speed $\mathrm{n}$ [rotations/minute] on the water content in the sludge $\mathrm{W}[\%]$.

Figure 3 presents the diagram of the impact of centrifugation time $\mathrm{t}$ [minutes] and centrifugation speed $\mathrm{n}$ [rotations/minute] for a specific dosage of flocculant Praestol 855BS C $\mathrm{F}_{\mathrm{F}}=28 \mathrm{ml} / \mathrm{dm}^{3}$ on the water content in the sludge $\mathrm{W}[\%]$.

Table 5 and Figure 4 present test results of the impact of dosage of flocculant Praestol $855 \mathrm{BS} \mathrm{C}_{\mathrm{F}}\left[\mathrm{ml} / \mathrm{dm}^{3}\right]$ on the water content in the sludge $\mathrm{W}[\%]$.

Final approximation equation describing diagrams in Figures 1, 2, 3, and 4, determined using the central point method according to Piecuch, received the following form:

$$
\begin{gathered}
\mathrm{W}\left(\mathbf{t}, \mathbf{n}, \mathbf{C}_{\mathbf{F}}\right)=81,90+\exp (1,66-0,40 \cdot \mathbf{t})+ \\
+\exp \left(2,41-3,18 \cdot 10^{-4} \cdot \mathbf{n}\right)+\exp \left(1,18-0,05 \cdot \mathbf{C}_{\mathbf{F}}\right)
\end{gathered}
$$

where:

$\mathrm{W}\left(\mathrm{t}, \mathrm{n}, \mathrm{C}_{\mathrm{F}}\right)$ - resultant parameter - water content in the sludge [\%],

$\mathrm{t}$ - centrifugation time [minutes],

$\mathrm{n}$ - centrifugation speed [rotations/minute],

$\mathrm{C}_{\mathrm{F}}$ - dosage of flocculant Praestol 855BS $\left[\mathrm{ml} / \mathrm{dm}^{3}\right]$.

\begin{tabular}{|c|c|c|c|c|}
\hline No. & $\begin{array}{c}\text { Variable } \\
\text { parameter }\end{array}$ & \multicolumn{2}{|c|}{ Fixed parameters } & $\begin{array}{l}\text { Resultant } \\
\text { parameter }\end{array}$ \\
\hline & $\begin{array}{c}\text { Centrifugation } \\
\text { time } \\
t \text { [minutes] }\end{array}$ & $\begin{array}{c}\text { Centrifugation } \\
\text { speed } \\
\mathrm{n} \text { [rotations/minute] }\end{array}$ & $\begin{array}{c}\text { Flocculant } \\
\text { dosage } \\
\mathrm{C}_{\mathrm{F}}\left[\mathrm{ml} / \mathrm{dm}^{3}\right]\end{array}$ & $\begin{array}{c}\text { Water content } \\
\text { in the sludge } \\
\text { W [\%] }\end{array}$ \\
\hline 1 & 1 & \multirow{5}{*}{2500} & \multirow{5}{*}{28} & 91.07 \\
\hline 2 & 2 & & & 90.02 \\
\hline 3 & 5 & & & 88.17 \\
\hline 4 & 8 & & & 87.98 \\
\hline 5 & 10 & & & 87.58 \\
\hline
\end{tabular}

Table 3. Test results of the impact of centrifugation time $t$ [minutes] on the water content in the sludge $\mathrm{W}$ [\%]

Table 4. Test results of the impact of centrifugation speed $\mathrm{n}$ [rotations/minute] on the water content in the sludge $\mathrm{W}$ [\%]

\begin{tabular}{|c|c|c|c|c|}
\hline No. & Variable parameter & \multicolumn{2}{|c|}{ Fixed parameters } & $\begin{array}{c}\text { Resultant } \\
\text { parameter }\end{array}$ \\
\hline & $\begin{array}{c}\text { Centrifugation } \\
\text { speed } \\
\mathrm{n} \text { [rotations/minute] }\end{array}$ & $\begin{array}{c}\text { Centrifugation } \\
\text { time } \\
\mathrm{t} \text { [minutes] }\end{array}$ & $\begin{array}{c}\text { Flocculant } \\
\text { dosage } \\
\mathrm{C}_{\mathrm{F}}\left[\mathrm{ml} / \mathrm{dm}^{3}\right]\end{array}$ & $\begin{array}{c}\text { Water content } \\
\text { in the sludge } \\
\mathrm{W}[\%]\end{array}$ \\
\hline 1 & 1000 & & & 93.15 \\
\hline 2 & 1500 & & \multirow{2}{*}{28} & 91.79 \\
\hline 3 & 2000 & & & 90.95 \\
\hline 4 & $\mathbf{2 5 0 0}$ & & & 90.02 \\
\hline 5 & 3000 & & & 89.35 \\
\hline
\end{tabular}



Fig. 1. Impact of centrifugation time $t$ [minutes] on the water content in the sludge $\mathrm{W}[\%]$

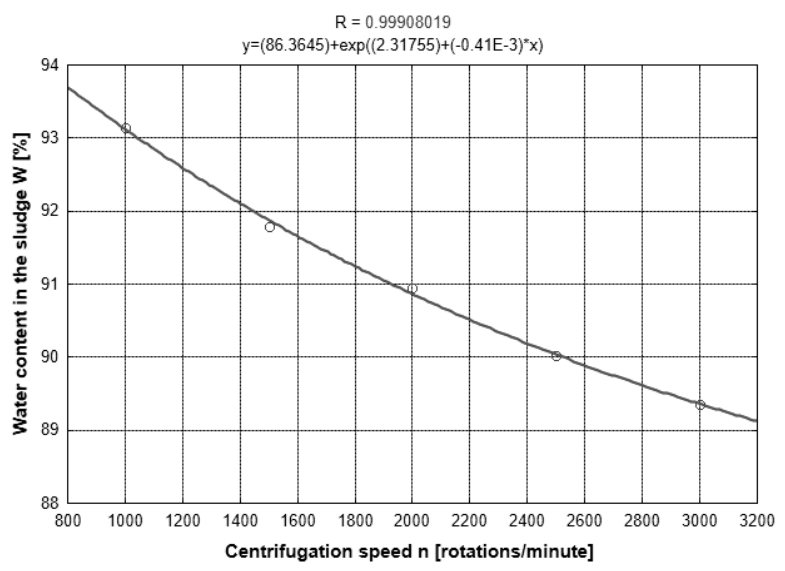

Fig. 2. Impact of centrifugation speed $\mathrm{n}$ [rotations/minute] on the water content in the sludge $\mathrm{W}$ [\%] 
The developed analytical and empirical equation is appropriate for the following ranges of parameter variability: $\mathrm{t} \in 1-10$ minutes,

$\mathrm{n} \in 1000-3000$ rotations/minute,

$\mathrm{C}_{\mathrm{F}} \in 0-48 \mathrm{ml} / \mathrm{dm}^{3}$,

hence it can be used for designing within this range.

$W=82.715+\exp \left(1.6566-0.3972^{*} x\right)+\exp \left(2.4062-3.1845^{*} 10^{\wedge}-4^{*} y\right)$

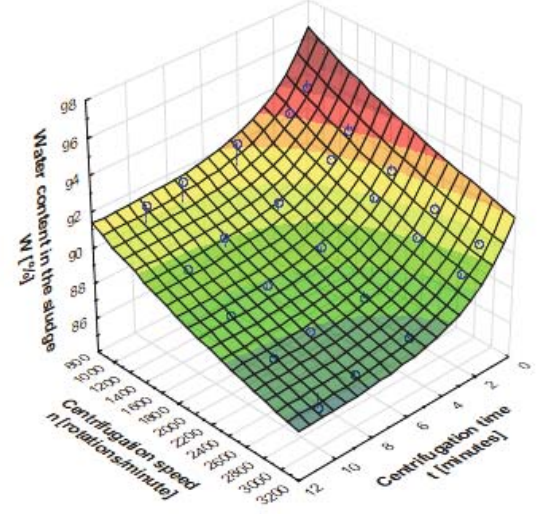

Fig. 3. Diagram of dependence of water content in the sludge $\mathrm{W}[\%]$ in the function of centrifugation time $t$ [minutes] and centrifugation speed $\mathrm{n}$ [rotations/minute] for a specific dosage of flocculant $C_{F}=28 \mathrm{ml} / \mathrm{dm}^{3}$
Table 6 and Figure 5 include test results of the impact of centrifugation time $\mathrm{t}$ [minutes] on the content of dry mass in reflux $\beta\left[\mathrm{mg} / \mathrm{dm}^{3}\right]$.

Table 7 and Figure 6 present test results of centrifugation speed $\mathrm{n}$ [rotations/minute] on the content of dry mass in reflux $\beta\left[\mathrm{mg} / \mathrm{dm}^{3}\right]$.

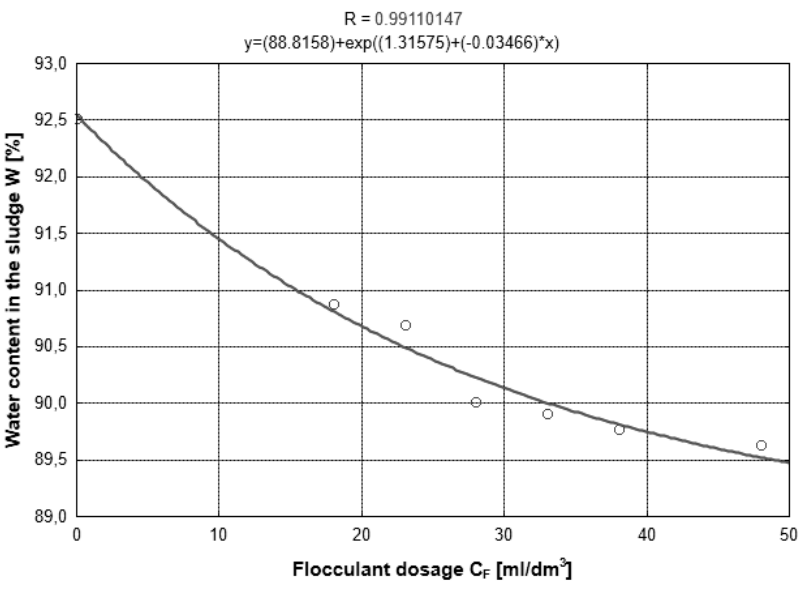

Fig. 4. Impact of the dosage of flocculant $C_{F}\left[\mathrm{ml} / \mathrm{dm}^{3}\right]$ on the water content in the sludge $\mathrm{W}[\%]$

Table 5. Test results of the impact of flocculant dosage $C_{F}\left[\mathrm{ml} / \mathrm{dm}^{3}\right]$ on the water content in the sludge $\mathrm{W}[\%]$

\begin{tabular}{|c|c|c|c|c|}
\hline No. & $\begin{array}{l}\text { Variable } \\
\text { parameter }\end{array}$ & \multicolumn{2}{|c|}{ Fixed parameters } & $\begin{array}{l}\text { Resultant } \\
\text { parameter }\end{array}$ \\
\hline & $\begin{array}{l}\text { Flocculant } \\
\text { dosage } \\
C_{F}\left[\mathrm{ml} / \mathrm{dm}^{3}\right]\end{array}$ & $\begin{array}{c}\text { Centrifugation } \\
\text { speed } \\
\mathrm{n} \text { [rotations/minute] }\end{array}$ & $\begin{array}{c}\text { Centrifugation } \\
\text { time } \\
\mathrm{t} \text { [minutes] }\end{array}$ & $\begin{array}{c}\text { Water content } \\
\text { in the sludge } \\
\text { W [\%] }\end{array}$ \\
\hline 1 & 0 & \multirow{7}{*}{2500} & \multirow{7}{*}{2} & 92.52 \\
\hline 2 & 18 & & & 90.88 \\
\hline 3 & 23 & & & 90.69 \\
\hline 4 & 28 & & & 90.02 \\
\hline 5 & 33 & & & 89.91 \\
\hline 6 & 38 & & & 89.77 \\
\hline 7 & 48 & & & 89.63 \\
\hline
\end{tabular}

Table 6. Test results of the impact of centrifugation time $\mathrm{t}$ [minutes] on the dry mass content in reflux $\beta$ [mg/dm $\left.{ }^{3}\right]$

\begin{tabular}{|c|c|c|c|c|}
\hline \multirow{2}{*}{ No. } & $\begin{array}{c}\text { Variable } \\
\text { parameter }\end{array}$ & \multicolumn{2}{|c|}{ Fixed parameters } & $\begin{array}{c}\text { Resultant } \\
\text { parameter }\end{array}$ \\
\cline { 2 - 2 } & $\begin{array}{c}\text { Centrifugation time } \\
\mathrm{t} \text { [minutes] }\end{array}$ & $\begin{array}{c}\text { Centrifugation speed } \\
\mathrm{n} \text { [rotations/minute] }\end{array}$ & $\begin{array}{c}\text { Flocculant } \\
\text { dosage } \\
\mathrm{C}_{\mathrm{F}}\left[\mathrm{m} / \mathrm{dm} \mathrm{dm}^{3}\right]\end{array}$ & $\begin{array}{c}\text { Dry mass } \\
\text { content in reflux } \\
\beta\left[\mathrm{mg} / \mathrm{dm}^{3}\right]\end{array}$ \\
\hline 1 & 1 & & & 1965.56 \\
\hline 2 & 2 & & \multirow{2}{*}{280} & 1733.00 \\
\hline 3 & 5 & & & 1688.58 \\
\hline 4 & 8 & & & 1667.76 \\
\hline 5 & 10 & & & 1616.22 \\
\hline
\end{tabular}


Figure 7 presents the diagram of the impact of centrifugation time $\mathrm{t}$ [minutes] and centrifugation speed $\mathrm{n}$ [rotations/minute] for a specific dosage of flocculant Praestol $855 \mathrm{BS} \mathrm{C}_{\mathrm{F}}=28 \mathrm{ml} / \mathrm{dm}^{3}$ on the dry mass content in reflux $\beta$ $\left[\mathrm{mg} / \mathrm{dm}^{3}\right]$.
Table 8 and Figure 8 present test results of the impact of dosage of flocculant Praestol $855 \mathrm{BS} \mathrm{C}_{\mathrm{F}}\left[\mathrm{ml} / \mathrm{dm}^{3}\right]$ on the dry mass content in reflux $\beta\left[\mathrm{mg} / \mathrm{dm}^{3}\right]$.

Final approximation equation of the diagrams in Figures 5, 6, 7 and 8, determined using central point method

Table 7. Test results of the impact of centrifugation speed $\mathrm{n}$ [rotations/minute] on the dry mass content in reflux $\beta\left[\mathrm{mg} / \mathrm{dm}^{3}\right.$ ]

\begin{tabular}{|c|c|c|c|c|}
\hline \multirow{2}{*}{ No. } & Variable parameter & \multicolumn{2}{|c|}{ Fixed parameters } & $\begin{array}{c}\text { Resultant } \\
\text { parameter }\end{array}$ \\
\cline { 2 - 2 } & $\begin{array}{c}\text { Centrifugation speed } \\
\mathrm{n} \text { [rotations/minute] }\end{array}$ & $\begin{array}{c}\text { Centrifugation time } \\
\mathrm{t} \text { [minutes] }\end{array}$ & $\begin{array}{c}\text { Flocculant } \\
\text { dosage } \\
\mathrm{C}_{\mathrm{F}}\left[\mathrm{ml} / \mathrm{dm}^{3}\right]\end{array}$ & $\begin{array}{c}\text { Dry mass } \\
\text { content in reflux } \\
\beta\left[\mathrm{mg} / \mathrm{dm}^{3}\right]\end{array}$ \\
\hline 1 & 1000 & & & 2247.61 \\
\hline 2 & 1500 & & \multirow{2}{*}{2} & 1959.53 \\
\hline 3 & 2000 & & & 1828.68 \\
\hline 4 & 2500 & & 1733.00 \\
\hline 5 & 3000 & & 1667.76 \\
\hline
\end{tabular}

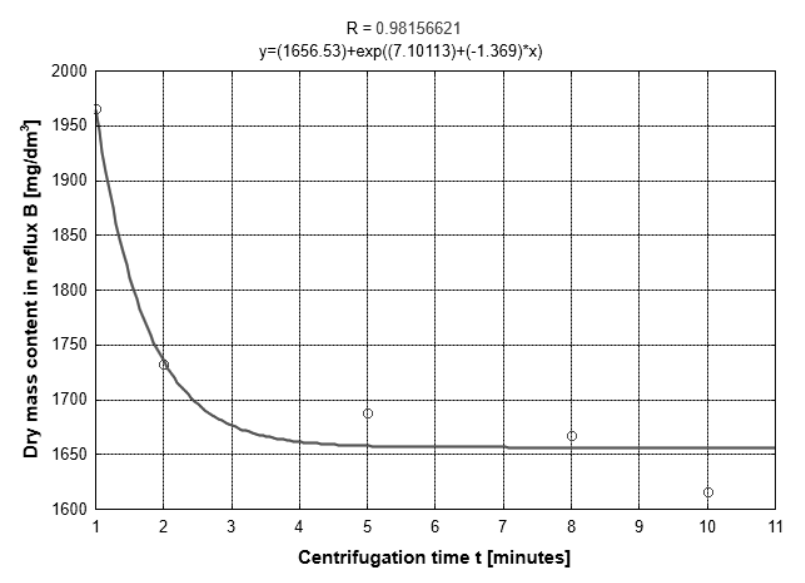

Fig. 5. Impact of centrifugation time $t$ [minutes] on the dry mass content in reflux $\beta\left[\mathrm{mg} / \mathrm{dm}^{3}\right]$

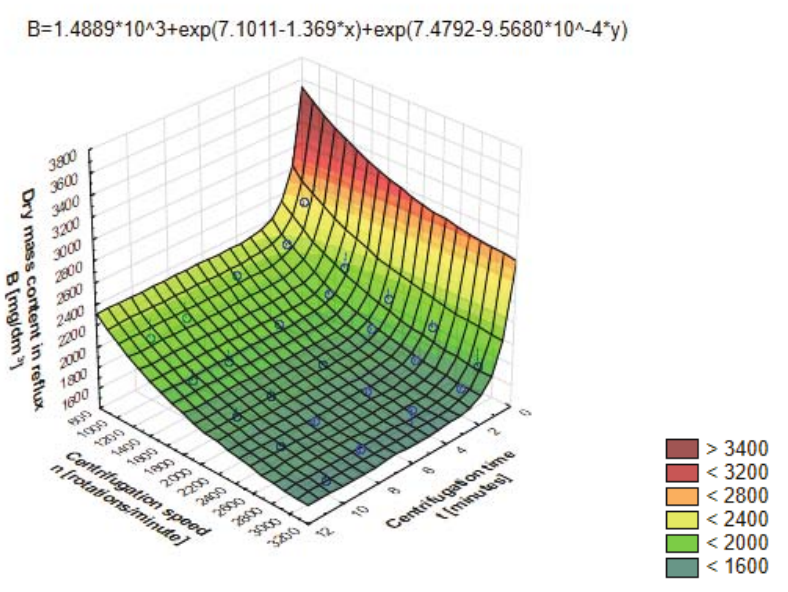

Fig. 7. Diagram of dependency of dry mass content in reflux $\beta\left[\mathrm{mg} / \mathrm{dm}^{3}\right]$ in the function of centrifugation time $t$ [minutes] and centrifugation speed $n$ [rotations/minute] for a specific dosage of flocculant $\mathrm{C}_{\mathrm{F}}=28 \mathrm{ml} / \mathrm{dm}^{3}$

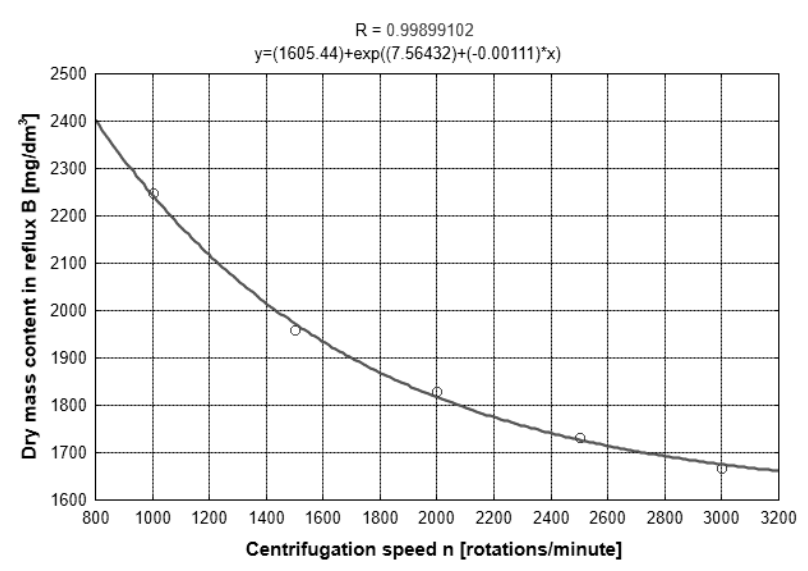

Fig. 6. Impact of centrifugation speed $\mathrm{n}$ [rotations/minute] on the dry mass content in reflux $\beta\left[\mathrm{mg} / \mathrm{dm}^{3}\right]$

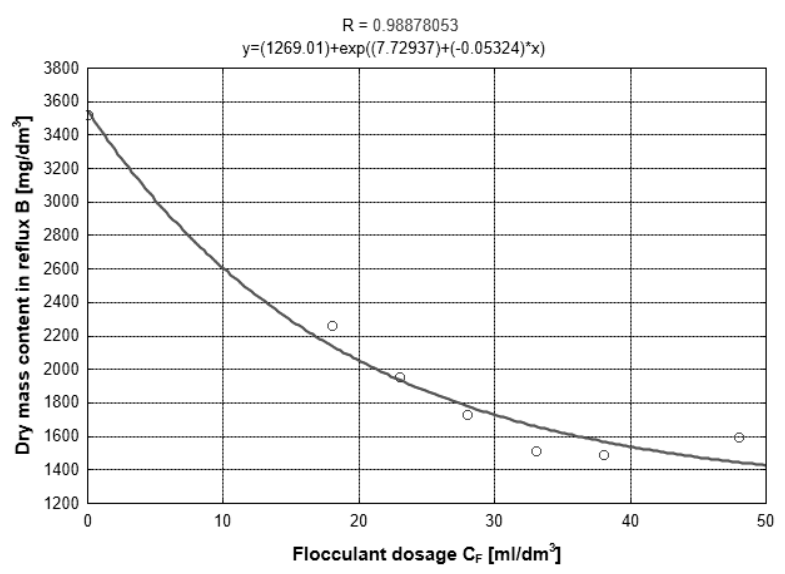

Fig. 8. Impact of dosage of flocculant $C_{F}\left[\mathrm{ml} / \mathrm{dm}^{3}\right]$ on the dry mass content in reflux $\beta\left[\mathrm{mg} / \mathrm{dm}^{3}\right]$ 
according to Piecuch, has the following analytical and empirical form:

$$
\begin{aligned}
& \beta\left(\mathbf{t}, \mathbf{n}, \mathbf{C}_{\mathbf{F}}\right)=-209,27+\exp (7,10-1,37 \cdot \mathbf{t})+ \\
& +\exp \left(7,48-9,57 \cdot 10^{-4} \cdot \mathbf{n}\right)+\exp \left(8,16-0,03 \cdot \mathbf{C}_{\mathrm{F}}\right)
\end{aligned}
$$

where:

$\beta\left(\mathrm{t}, \mathrm{n}, \mathrm{C}_{\mathrm{F}}\right)$ - resultant parameter - dry mass content in the reflux $\left[\mathrm{mg} / \mathrm{dm}^{3}\right]$,

$\mathrm{t}$ - centrifugation time [minutes], $\mathrm{n}$ - centrifugation speed [rotations/minute],

$\mathrm{C}_{\mathrm{F}}$ - dosage of flocculant Praestol 855BS $\left[\mathrm{ml} / \mathrm{dm}^{3}\right]$.

The developed equation is appropriate for the following ranges of parameter variability:

$\mathrm{t} \in 1-10$ minutes,

$\mathrm{n} \in 1000-3000$ rotations/minute,

$\mathrm{C}_{\mathrm{F}} \in 0-48 \mathrm{ml} / \mathrm{dm}^{3}$,

hence the designer can use them within these ranges.

Table 9 and Figure 9 present test results of the impact of centrifugation time $\mathrm{t}$ [minutes] on the water content in the sludge $\mathrm{W}[\%]$.

Table 8. Test results of the impact of dosage of flocculant $C_{F}\left[\mathrm{ml}^{2} \mathrm{dm}^{3}\right]$ on the dry mass content

\begin{tabular}{|c|c|c|c|c|}
\hline No. & Variable & \multicolumn{2}{|c|}{ Fixed parameters } & Resultant \\
\hline & $\begin{array}{l}\text { Flocculant dosage } \\
\qquad C_{F}\left[\mathrm{ml} / \mathrm{dm}^{3}\right]\end{array}$ & $\begin{array}{c}\text { Centrifugation speed } \\
\mathrm{n} \text { [rotations/minute] }\end{array}$ & $\begin{array}{c}\text { Centrifugation time } \\
t \text { [minutes] }\end{array}$ & $\begin{array}{c}\text { Dry mass } \\
\text { content in reflux } \\
\beta\left[\mathrm{mg} / \mathrm{dm}^{3}\right]\end{array}$ \\
\hline 1 & 0 & \multirow{7}{*}{2500} & \multirow{7}{*}{2} & 3525.08 \\
\hline 2 & 18 & & & 2267.51 \\
\hline 3 & 23 & & & 1953.61 \\
\hline 4 & 28 & & & 1733.00 \\
\hline 5 & 33 & & & 1513.84 \\
\hline 6 & 38 & & & 1489.92 \\
\hline 7 & 48 & & & 1596.59 \\
\hline
\end{tabular}
in reflux $\beta\left[\mathrm{mg} / \mathrm{dm}^{3}\right]$

\begin{tabular}{|c|c|c|c|c|}
\hline \multirow[b]{2}{*}{ No. } & \multirow{2}{*}{$\begin{array}{c}\text { Variable } \\
\text { parameter } \\
\begin{array}{c}\text { Centrifugation time } \\
\mathrm{t} \text { [minutes] }\end{array}\end{array}$} & \multicolumn{2}{|c|}{ Fixed parameters } & $\begin{array}{l}\text { Resultant } \\
\text { parameter }\end{array}$ \\
\hline & & $\begin{array}{c}\text { Centrifugation speed } \\
\text { n [rotations/minute] }\end{array}$ & $\begin{array}{c}\text { Dosage of flocculant }(50 \%) \\
+ \text { oil }(50 \%) \\
C_{\mathrm{F} / \mathrm{O}}\left[\mathrm{ml}^{3} / \mathrm{dm}^{3}\right]\end{array}$ & $\begin{array}{c}\text { Water content } \\
\text { in the sludge } \\
\text { W [\%] }\end{array}$ \\
\hline 1 & 1 & \multirow{5}{*}{2500} & \multirow{5}{*}{28} & 91.28 \\
\hline 2 & 2 & & & 90.47 \\
\hline 3 & 5 & & & 88.86 \\
\hline 4 & 8 & & & 88.14 \\
\hline 5 & 10 & & & 87.82 \\
\hline
\end{tabular}

Table 9. Test results of the impact of centrifugation time $\mathrm{t}$ [minutes] on the water content in the sludge $\mathrm{W}$ [\%]

\begin{tabular}{|c|c|c|c|c|}
\hline \multirow[b]{2}{*}{ No. } & \multirow{2}{*}{$\begin{array}{c}\text { Variable parameter } \\
\text { Centrifugation speed } \\
\text { n [rotations/minute] }\end{array}$} & \multicolumn{2}{|c|}{ Fixed parameters } & \multirow{2}{*}{$\begin{array}{c}\text { Resultant } \\
\text { parameter } \\
\text { Water content in } \\
\text { the sludge } \\
\text { W [\%] }\end{array}$} \\
\hline & & $\begin{array}{c}\text { Centrifugation time } \\
t \text { [minutes] }\end{array}$ & $\begin{array}{c}\text { Dosage of flocculant }(50 \%) \\
+ \text { oil }(50 \%) \\
C_{F / O}\left[\mathrm{ml}^{3} / \mathrm{dm}^{3}\right]\end{array}$ & \\
\hline 1 & 1000 & \multirow{5}{*}{2} & \multirow{5}{*}{28} & 93.81 \\
\hline 2 & 1500 & & & 92.71 \\
\hline 3 & 2000 & & & 91.74 \\
\hline 4 & 2500 & & & 90.47 \\
\hline 5 & 3000 & & & 90.30 \\
\hline
\end{tabular}

Table 10. Test results of centrifugation speed $\mathrm{n}$ [rotations/minute] on the water content in the sludge $\mathrm{W}$ [\%] 
Table 10 and Figure 10 present test results of the impact of centrifugation speed $\mathrm{n}$ [rotations/minute] on the water content in the sludge $\mathrm{W}[\%]$.

Figure 11 presents the diagram of centrifugation time $\mathrm{t}$ [minutes] and centrifugation speed $\mathrm{n}$ [rotations/minute] for a specific dosage of mixture of flocculant Praestol 855BS $(50 \%)+$ orange oil $(50 \%) \mathrm{C}_{\mathrm{F} / \mathrm{O}}=28 \mathrm{ml} / \mathrm{dm}^{3}$ on the water content in the sludge $\mathrm{W}[\%]$.

Table 11 and Figure 12 present test results of the impact of the dosage of mixture of flocculant Prestol 855BS (50\%) + orange oil $(50 \%) \mathrm{C}_{\mathrm{F} / \mathrm{O}}\left[\mathrm{ml} / \mathrm{dm}^{3}\right]$ on the water content in the sludge $\mathrm{W}[\%]$.

Final approximation equation determined using the central point method according to Piecuch received the following form:

$$
\begin{gathered}
\mathrm{W}\left(\mathbf{t}, \mathbf{n}, \mathbf{C}_{\mathbf{F / O}}\right)=81,75+\exp (1,60-0,24 \cdot \mathbf{t})+ \\
+\exp \left(2,28-3,63 \cdot 10^{-4} \cdot \mathbf{n}\right)+\exp \left(1,18-0,02 \cdot \mathbf{C}_{\mathbf{F} / \mathbf{O}}\right)
\end{gathered}
$$

where:

$\mathrm{W}\left(\mathrm{t}, \mathrm{n}, \mathrm{C}_{\mathrm{F} / \mathrm{O}}\right)$ - resultant parameter - water content in the sludge $[\%]$,



Fig. 9. Impact of centrifugation time $t$ [minutes] on the water content in the sludge W [\%]

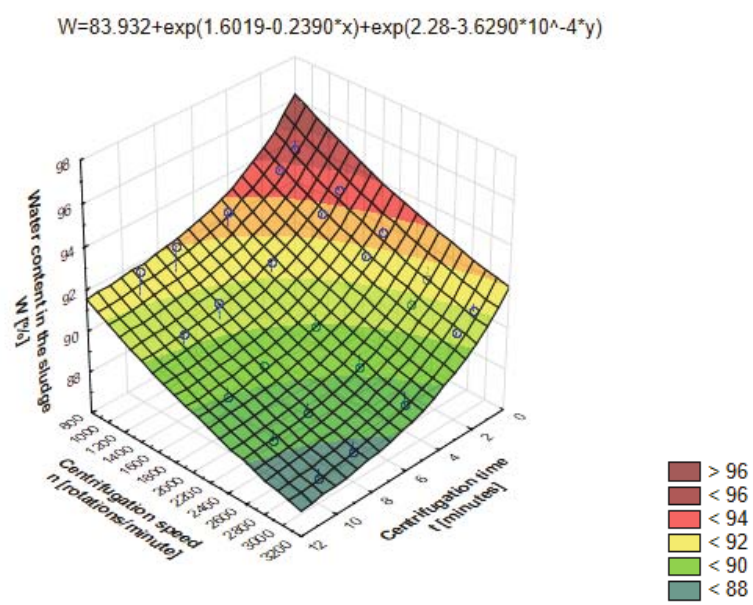

Fig. 11. Diagram of dependency of water content in the sludge $\mathrm{W}[\%]$ in the function of centrifugation time $t$ [minutes] and centrifugation speed $\mathrm{n}$ [rotations/minute] for a specific dosage of mixture of flocculant $(50 \%)+$ oil $(50 \%) C_{F / O}=28 \mathrm{ml} / \mathrm{dm}^{3}$ $\mathrm{t}$ - centrifugation time [minutes],

$\mathrm{n}$ - centrifugation speed [rotations/minute],

$\mathrm{C}_{\mathrm{F} / \mathrm{O}}$ - dosage of mixture of flocculant Praestol 855BS (50\%) + orange oil $(50 \%)\left[\mathrm{ml} / \mathrm{dm}^{3}\right]$.

The developed equation is appropriate for the following ranges of parameters variability:

$\mathrm{t} \in 1-10$ minutes,

$\mathrm{n} \in 1000-3000$ rotations/minute,

$\mathrm{C}_{\mathrm{F} / \mathrm{O}} \in 0-48 \mathrm{ml} / \mathrm{dm}^{3}$,

and it can be used in the designing within these ranges.

Table 12 and Figure 13 present test results of the impact of centrifugation time $\mathrm{t}$ [minutes] on the dry mass content in reflux $\beta\left[\mathrm{mg} / \mathrm{dm}^{3}\right]$.

Table 13 and Figure 14 include test results of the impact of centrifugation speed $\mathrm{n}$ [rotations/minute] on the dry mass content in reflux $\beta\left[\mathrm{mg} / \mathrm{dm}^{3}\right]$.

Figure 15 presents the diagram of the impact of centrifugation time $\mathrm{t}$ [minutes] and centrifugation speed $\mathrm{n}$ [rotations/minute] for a specific dosage of mixture of flocculant Praestol 855BS (50\%) + orange oil $(50 \%) \mathrm{C}_{\mathrm{F} / \mathrm{O}}=28 \mathrm{ml} / \mathrm{dm}^{3}$ on the dry mass content in reflux $\beta\left[\mathrm{mg} / \mathrm{dm}^{3}\right]$.

Table 14 and Figure 16 present test results of the impact of dosage of mixture of flocculant Praestol 855BS (50\%) +

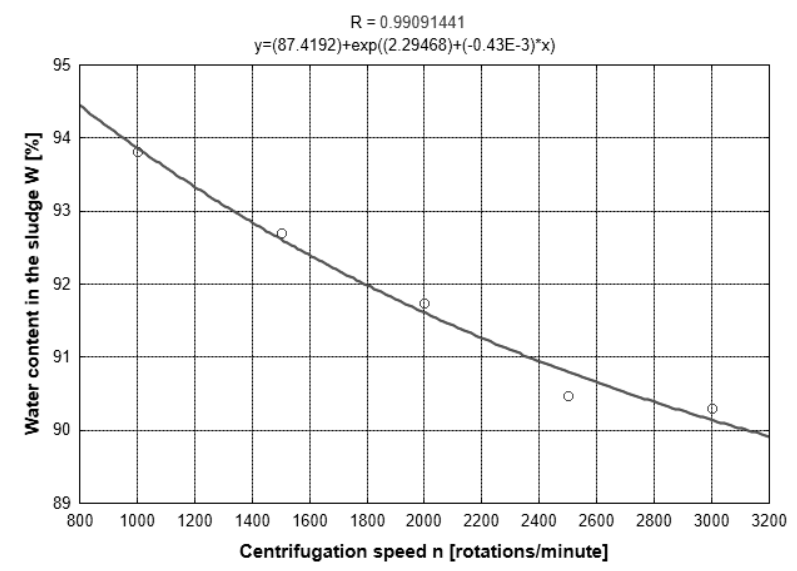

Fig. 10. Impact of centrifugation speed $\mathrm{n}$ [rotations/minute] on the water content in the sludge $\mathrm{W}[\%]$

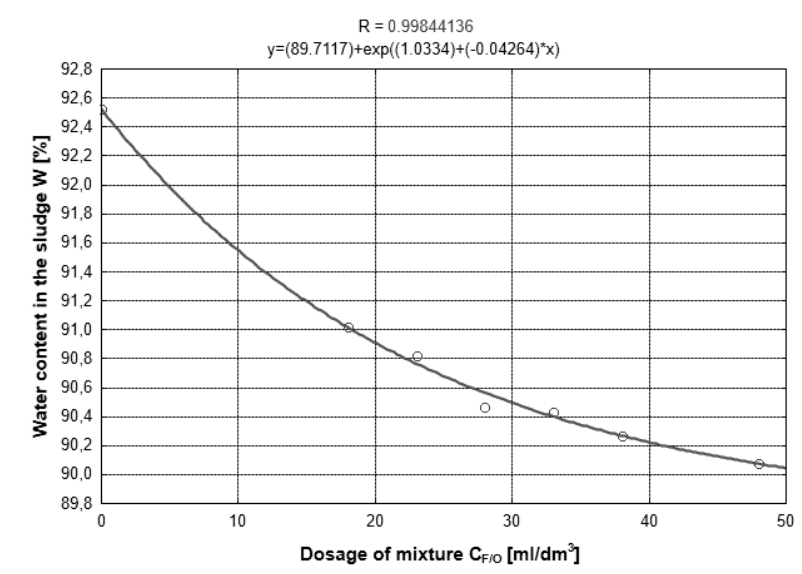

Fig. 12. Impact of the dosage of mixture of flocculant (50\%) + oil $(50 \%) \mathrm{C}_{\mathrm{F} / \mathrm{O}}\left[\mathrm{ml}^{2} / \mathrm{dm}^{3}\right]$ on the water content in the sludge $\mathrm{W}[\%]$ 
Table 11. Test results of the impact of the dosage of mixture of flocculant $(50 \%)+$ oil $(50 \%) \mathrm{C}_{\mathrm{F} / \mathrm{O}}\left[\mathrm{ml}^{\mathrm{d}} / \mathrm{dm}^{3}\right]$ on the water content in the sludge $\mathrm{W}$ [\%]

\begin{tabular}{|c|c|c|c|c|}
\hline \multirow[b]{2}{*}{ No. } & \multirow{2}{*}{$\begin{array}{c}\text { Variable } \\
\text { parameter } \\
\text { Dosage of flocculant }(50 \%) \\
+ \text { oil }(50 \%) \\
\mathrm{C}_{\mathrm{F} / \mathrm{O}}\left[\mathrm{ml} / \mathrm{dm}^{3}\right]\end{array}$} & \multicolumn{2}{|c|}{ Fixed parameters } & $\begin{array}{l}\text { Resultant } \\
\text { parameter }\end{array}$ \\
\hline & & $\begin{array}{c}\text { Centrifugation speed } \\
\text { n [rotations/minute] }\end{array}$ & $\begin{array}{c}\text { Centrifugation time } \\
\mathrm{t} \text { [minutes] }\end{array}$ & $\begin{array}{c}\text { Water content } \\
\text { in the sludge } \\
\text { W [\%] }\end{array}$ \\
\hline 1 & 0 & \multirow{7}{*}{2500} & \multirow{7}{*}{2} & 92.52 \\
\hline 2 & 18 & & & 91.02 \\
\hline 3 & 23 & & & 90.82 \\
\hline 4 & 28 & & & 90.47 \\
\hline 5 & 33 & & & 90.43 \\
\hline 6 & 38 & & & 90.27 \\
\hline 7 & 48 & & & 90.08 \\
\hline
\end{tabular}

Table 12. Test results of the impact of centrifugation time $\mathrm{t}$ [minutes] on the dry mass content in reflux $\beta$ [mg/dm ${ }^{3}$ ]

\begin{tabular}{|c|c|c|c|c|}
\hline \multirow[b]{2}{*}{ No. } & \multirow{2}{*}{$\begin{array}{c}\text { Variable } \\
\text { parameter } \\
\begin{array}{c}\text { Centrifugation time } \\
t \text { [minutes] }\end{array}\end{array}$} & \multicolumn{2}{|c|}{ Fixed parameters } & \multirow{2}{*}{$\begin{array}{c}\text { Resultant } \\
\text { parameter } \\
\text { Dry mass content } \\
\text { in reflux } \\
\beta\left[\mathrm{mg} / \mathrm{dm}^{3}\right]\end{array}$} \\
\hline & & $\begin{array}{l}\text { Centrifugation speed } \\
\text { n [rotations/minute] }\end{array}$ & $\begin{array}{c}\text { Dosage of flocculant }(50 \%) \\
+ \text { oil }(50 \%) \\
C_{\mathrm{F} / \mathrm{O}}\left[\mathrm{ml}^{3} / \mathrm{dm}^{3}\right]\end{array}$ & \\
\hline 1 & 1 & \multirow{5}{*}{2500} & \multirow{5}{*}{28} & 2304.22 \\
\hline 2 & 2 & & & 2223.92 \\
\hline 3 & 5 & & & 2054.94 \\
\hline 4 & 8 & & & 1995.17 \\
\hline 5 & 10 & & & 1972.39 \\
\hline
\end{tabular}

Table 13. Test results of the impact of centrifugation speed $n$ [rotations/minute] on the dry mass content in reflux $\beta$ [mg/dm ${ }^{3}$ ]

\begin{tabular}{|c|c|c|c|c|}
\hline \multirow[b]{2}{*}{ No. } & \multirow{2}{*}{$\begin{array}{c}\text { Variable parameter } \\
\text { Centrifugation speed } \\
\text { n [rotations/minute] }\end{array}$} & \multicolumn{2}{|c|}{ Fixed parameters } & \multirow{2}{*}{$\begin{array}{c}\begin{array}{c}\text { Resultant } \\
\text { parameter }\end{array} \\
\text { Dry mass content } \\
\text { in reflux } \\
\beta\left[\mathrm{mg} / \mathrm{dm}^{3}\right] \\
\end{array}$} \\
\hline & & $\begin{array}{c}\text { Centrifugation time } \\
t \text { [minutes] }\end{array}$ & $\begin{array}{c}\text { Dosage of flocculant }(50 \%) \\
+ \text { oil }(50 \%) \\
C_{5}\left[\mathrm{ml}^{2} / \mathrm{dm}^{3}\right]\end{array}$ & \\
\hline 1 & 1000 & \multirow{5}{*}{2} & \multirow{5}{*}{28} & 4079.23 \\
\hline 2 & 1500 & & & 2710.29 \\
\hline 3 & 2000 & & & 2292.94 \\
\hline 4 & 2500 & & & 2223.92 \\
\hline 5 & 3000 & & & 2125.26 \\
\hline
\end{tabular}

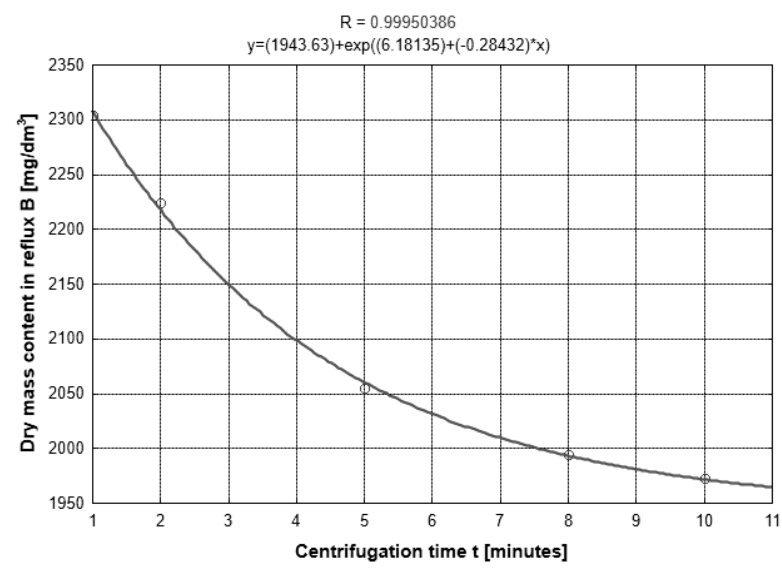

Fig. 13. Impact of centrifugation time $t$ [minutes] on the dry mass content in reflux $\beta\left[\mathrm{mg} / \mathrm{dm}^{3}\right]$

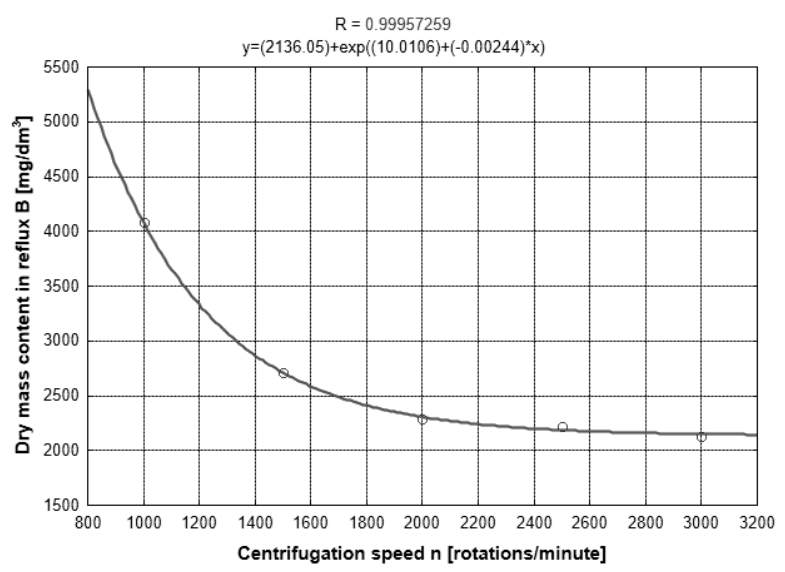

Fig. 14. Impact of centrifugation speed $\mathrm{n}$ [rotations/minute] on the dry mass content in reflux $\beta\left[\mathrm{mg} / \mathrm{dm}^{3}\right]$ 
orange oil $(50 \%) \mathrm{C}_{\mathrm{F} / \mathrm{O}}\left[\mathrm{ml} / \mathrm{dm}^{3}\right]$ on the dry mass content in reflux $\beta\left[\mathrm{mg} / \mathrm{dm}^{3}\right]$.

Final approximation equation calculated using the central point method according to Piecuch has the following form:

$$
\begin{gathered}
\quad \beta\left(\mathbf{t}, \mathbf{n}, \mathbf{C}_{\mathbf{F} / \mathbf{O}}\right)=1,64 \cdot 10^{3}+\exp (6,18-0,28 \cdot \mathbf{t})+ \\
+\exp \left(9,95-2,4 \cdot 10^{-3} \cdot \mathbf{n}\right)+\exp \left(7,35-0,07 \cdot \mathbf{C}_{\mathbf{F} / \mathbf{O}}\right)
\end{gathered}
$$

where:

$\beta\left(\mathrm{t}, \mathrm{n}, \mathrm{C}_{\mathrm{F} / \mathrm{O}}\right)$ - resultant parameter - dry mass content in the reflux $\left[\mathrm{mg} / \mathrm{dm}^{3}\right]$,

$\mathrm{t}$ - centrifugation time [minutes],

$\mathrm{n}$ - centrifugation speed [rotations/minute],

$\mathrm{C}_{\mathrm{F} / \mathrm{O}}$ - dosage of the mixture of flocculant Praestol 855BS $(50 \%)+$ orange oil $(50 \%)\left[\mathrm{ml} / \mathrm{dm}^{3}\right]$.

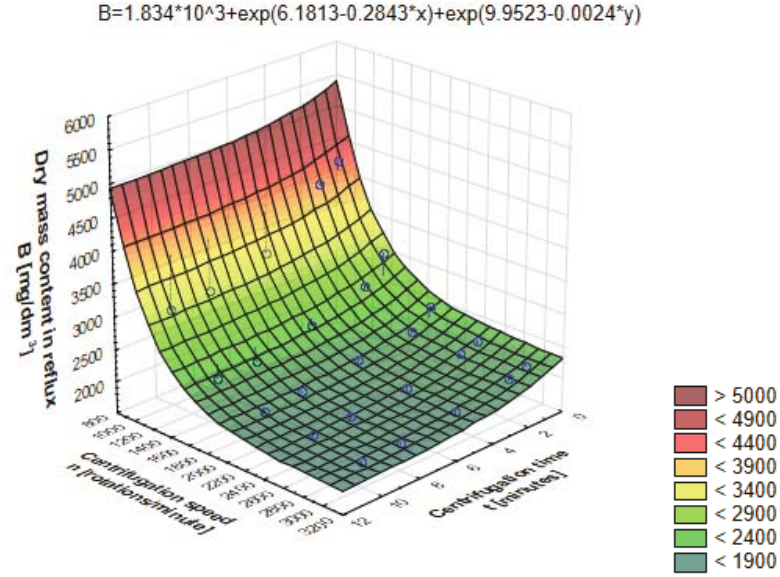

Fig. 15. Diagram of dependency of dry mass content in reflux $\beta\left[\mathrm{mg} / \mathrm{dm}^{3}\right]$ in the function of centrifugation time $\mathrm{t}$ [minutes] and centrifugation speed $\mathrm{n}$ [rotations/minute] for a specific dosage of mixture of flocculant $(50 \%)+$ oil $(50 \%) \mathrm{C}_{\mathrm{F} / \mathrm{O}}=28\left[\mathrm{ml} / \mathrm{dm}^{3}\right]$

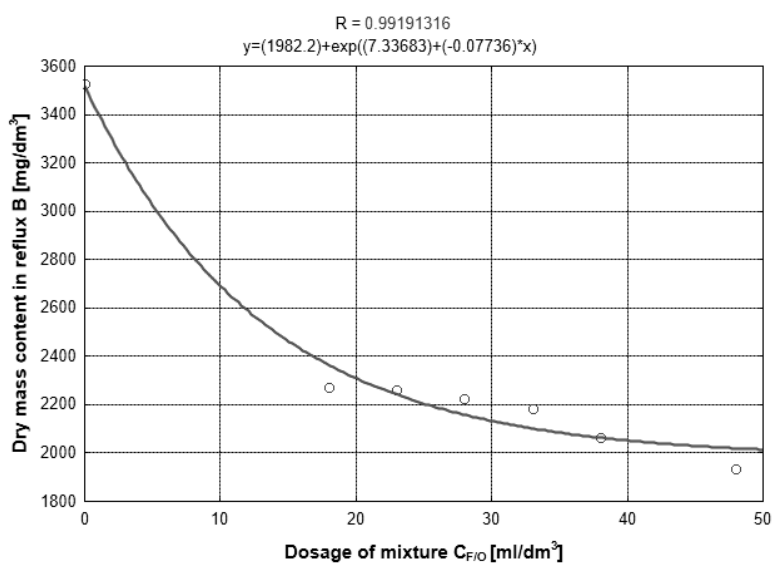

Fig. 16. Ilmpact of the dosage of mixture of flocculant $(50 \%)$ + oil $(50 \%) \mathrm{C}_{\mathrm{F} / \mathrm{O}}\left[\mathrm{ml}^{2} \mathrm{dm}^{3}\right]$ on the dry mass content in reflux $\beta\left[\mathrm{mg} / \mathrm{dm}^{3}\right]$

Table 14. Test results of the impact of dosage of mixture of flocculant $(50 \%)+$ oil $(50 \%) \mathrm{C}_{\mathrm{F} / \mathrm{O}}\left[\mathrm{ml}^{2} \mathrm{dm}^{3}\right]$

\begin{tabular}{|c|c|c|c|c|}
\hline \multirow[b]{2}{*}{ No. } & \multirow{2}{*}{$\begin{array}{c}\text { Variable } \\
\text { parameter } \\
\text { Dosage of flocculant }(50 \%) \\
+ \text { oil }(50 \%) \\
\mathrm{C}_{\mathrm{F} / \mathrm{O}}\left[\mathrm{ml} / \mathrm{dm}^{3}\right]\end{array}$} & \multicolumn{2}{|c|}{ Fixed parameters } & $\begin{array}{l}\text { Resultant } \\
\text { parameter }\end{array}$ \\
\hline & & $\begin{array}{c}\text { Centrifugation } \\
\text { speed } \\
\mathrm{n} \text { [rotations/minute] }\end{array}$ & $\begin{array}{c}\text { Centrifugation } \\
\text { time } \\
t \text { [minutes] }\end{array}$ & $\begin{array}{l}\text { Dry mass content in reflux } \\
\qquad \beta\left[\mathrm{mg} / \mathrm{dm}^{3}\right]\end{array}$ \\
\hline 1 & 0 & \multirow{7}{*}{2500} & \multirow{7}{*}{2} & 3525.08 \\
\hline 2 & 18 & & & 2273.61 \\
\hline 3 & 23 & & & 2261.91 \\
\hline 4 & 28 & & & 2223.92 \\
\hline 5 & 33 & & & 2184.24 \\
\hline 6 & 38 & & & 2064.83 \\
\hline 7 & 48 & & & 1932.75 \\
\hline
\end{tabular}
on the dry mass content in reflux $\beta\left[\mathrm{mg} / \mathrm{dm}^{3}\right]$

\begin{tabular}{|c|c|c|c|c|}
\hline \multirow[b]{2}{*}{ No. } & $\begin{array}{c}\text { Variable } \\
\text { parameter }\end{array}$ & \multicolumn{2}{|c|}{ Fixed parameters } & $\begin{array}{c}\text { Resultant } \\
\text { parameter }\end{array}$ \\
\hline & $\begin{array}{c}\text { Centrifugation time } \\
\mathrm{t} \text { [minutes] }\end{array}$ & $\begin{array}{c}\text { Centrifugation speed } \\
\text { n [rotations/minute] }\end{array}$ & $\begin{array}{c}\text { Dosage of flocculant }(50 \%) \\
+ \text { oil }(50 \%) \\
C_{\mathrm{F} / \mathrm{O}}\left[\mathrm{ml} / \mathrm{dm}^{3}\right]\end{array}$ & $\begin{array}{c}\text { Time of } \\
\text { maintenance of smell } \\
\text { in the sludge } \\
\mathrm{T} \text { [minutes] }\end{array}$ \\
\hline 1 & 1 & \multirow{5}{*}{2500} & \multirow{5}{*}{28} & 38 \\
\hline 2 & 2 & & & 31 \\
\hline 3 & 5 & & & 27 \\
\hline 4 & 8 & & & 24 \\
\hline 5 & 10 & & & 20 \\
\hline
\end{tabular}

Table 15. Test results of the impact of centrifugation time $t$ [minutes] on time of maintenance of smell in the sludge $\mathrm{T}$ [minutes] 
The developed equation is appropriate for the following ranges of parameter variability:

$\mathrm{t} \in 1-10$ minutes,

$\mathrm{n} \in 1000-3000$ rotations/minute,

$\mathrm{C}_{\mathrm{F} / \mathrm{O}} \in 0-48 \mathrm{ml} / \mathrm{dm}^{3}$,

hence it can be used by the designers within these ranges.
Table 15 and Figure 17 include test results of the impact of centrifugation time $t$ [minutes] on time of maintenance of smell in the sludge $\mathrm{T}$ [minutes].

Table 16 and Figure 18 include test results of the impact of centrifugation speed $\mathrm{n}$ [rotations/minute] on time of maintenance of smell in the sludge $\mathrm{T}$ [minutes].

Table 16. Test results of the impact of centrifugation speed $n$ [rotations/minute] on time of maintenance of smell in the sludge $\mathrm{T}$ [minutes]

\begin{tabular}{|c|c|c|c|c|}
\hline \multirow[b]{2}{*}{ No. } & \multirow{2}{*}{$\begin{array}{c}\text { Variable parameter } \\
\begin{array}{c}\text { Centrifugation speed } \\
\text { n [rotations/minute] }\end{array}\end{array}$} & \multicolumn{2}{|c|}{ Fixed parameters } & \multirow{2}{*}{$\begin{array}{c}\text { Resultant } \\
\text { parameter }\end{array}$} \\
\hline & & $\begin{array}{c}\text { Centrifugation time } \\
t \text { [minutes] }\end{array}$ & $\begin{array}{c}\text { Dosage of flocculant }(50 \%)+ \\
\text { oil }(50 \%) \\
\mathrm{C}_{\mathrm{F} / \mathrm{O}}\left[\mathrm{ml} / \mathrm{dm}^{3}\right]\end{array}$ & \\
\hline 1 & 1000 & \multirow{5}{*}{2} & \multirow{5}{*}{28} & 44 \\
\hline 2 & 1500 & & & 37 \\
\hline 3 & 2000 & & & 36 \\
\hline 4 & 2500 & & & 31 \\
\hline 5 & 3000 & & & 30 \\
\hline
\end{tabular}

Table 17. Test results of the impact of dosage of mixture of flocculant $(50 \%)+$ oil $(50 \%) C_{F / O}\left[\mathrm{ml}^{2} / \mathrm{dm}^{3}\right]$ on time of maintenance of smell in the sludge $\mathrm{T}$ [minutes]

\begin{tabular}{|c|c|c|c|c|}
\hline \multirow[b]{2}{*}{ No. } & \multirow{2}{*}{$\begin{array}{c}\begin{array}{c}\text { Variable } \\
\text { parameter }\end{array} \\
\text { Dosage of flocculant }(50 \%) \\
+ \text { oil }(50 \%) \\
\mathrm{C}_{\mathrm{F} / \mathrm{O}}\left[\mathrm{ml} / \mathrm{dm}^{3}\right]\end{array}$} & \multicolumn{2}{|c|}{ Fixed parameters } & $\begin{array}{l}\text { Resultant } \\
\text { parameter }\end{array}$ \\
\hline & & $\begin{array}{c}\text { Centrifugation speed } \\
\mathrm{n} \text { [rotations/minute] }\end{array}$ & $\begin{array}{c}\text { Centrifugation time } \\
\mathrm{t} \text { [minutes] }\end{array}$ & $\begin{array}{c}\text { Time of maintenance } \\
\text { of smell in the sludge } \\
\mathrm{T} \text { [minutes] }\end{array}$ \\
\hline 1 & 0 & \multirow{7}{*}{2500} & \multirow{7}{*}{2} & 0 \\
\hline 2 & 18 & & & 21 \\
\hline 3 & 23 & & & 25 \\
\hline 4 & 28 & & & 31 \\
\hline 5 & 33 & & & 39 \\
\hline 6 & 38 & & & 44 \\
\hline 7 & 48 & & & 52 \\
\hline
\end{tabular}

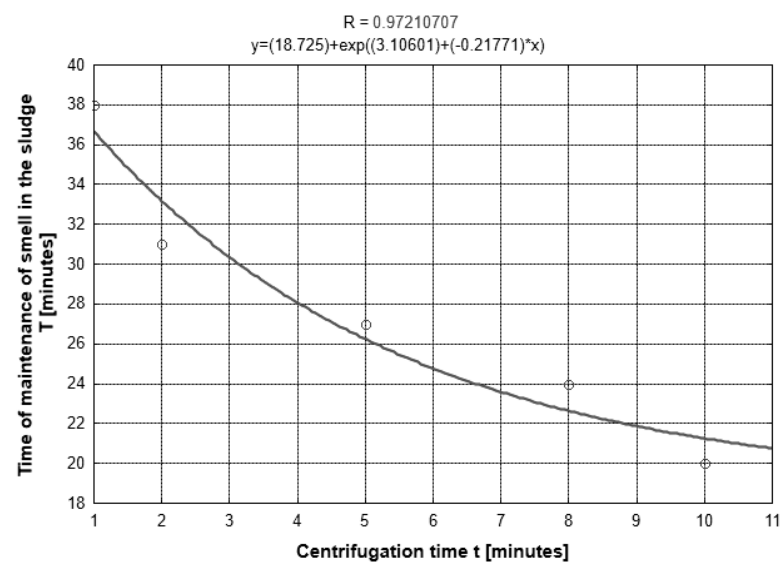

Fig. 17. Impact of centrifugation time $t$ [minutes] on time of maintenance of smell in the sludge $\mathrm{T}$ [minutes]

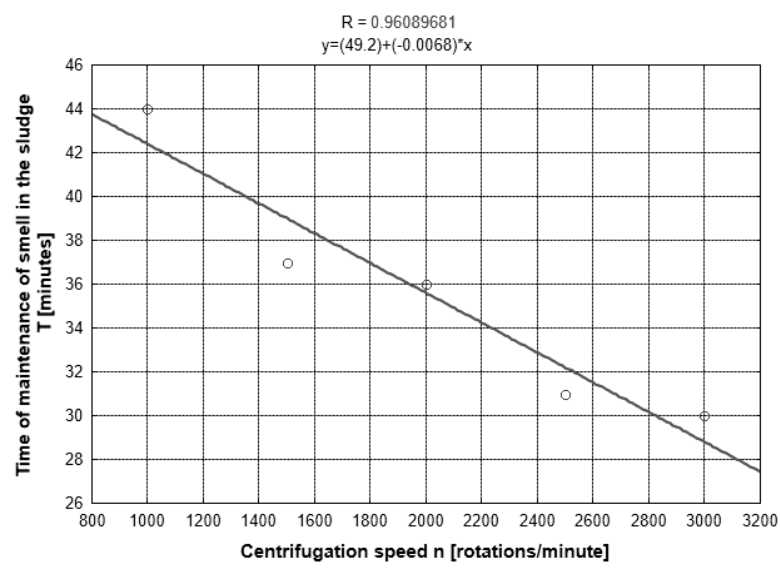

Fig. 18. Impact of centrifugation speed $\mathrm{n}$ [rotations/minute] on time of maintenance of smell in the sludge $T$ [minutes] 
Figure 19 presents the diagram of the impact of centrifugation time $\mathrm{t}$ [minutes] and centrifugation speed $\mathrm{n}$ [rotations/minute] for a specific dosage of mixture of flocculant Praestol 855BS (50\%) + orange oil $(50 \%) \mathrm{C}_{\mathrm{F} / \mathrm{O}}=28 \mathrm{ml} / \mathrm{dm}^{3}$ on time of maintenance of smell in the sludge $\mathrm{T}$ [minutes].

Table 17 and Figure 20 include test results of the impact of dosage of mixture of flocculant Praestol 855BS (50\%) + orange oil $(50 \%) \mathrm{C}_{\mathrm{F} / \mathrm{O}}\left[\mathrm{ml} / \mathrm{dm}^{3}\right]$ on time of maintenance of smell in the sludge $\mathrm{T}$ [minutes].

The approximation equation using the central point method according to Piecuch receives the following form:

$$
\begin{gathered}
\mathrm{T}\left(\mathbf{t}, \mathbf{n}, \mathbf{C}_{\mathbf{F} / \mathbf{0}}\right)=3,35+\exp (3,11-0,22 \cdot \mathbf{t})- \\
-7 \cdot 10^{-3} \cdot \mathbf{n}+1,15 \cdot \mathbf{C}_{\mathbf{F} / \mathbf{O}}
\end{gathered}
$$

where:

$\mathrm{T}\left(\mathrm{t}, \mathrm{n}, \mathrm{C}_{\mathrm{F} / \mathrm{O}}\right)$ - resultant parameter - time of maintenance of smell in the sludge [minutes],

$\mathrm{t}$ - centrifugation time [minutes],

$\mathrm{n}$ - centrifugation speed [rotations/minute],

$\mathrm{C}_{\mathrm{F} / \mathrm{O}}$ - dosage of mixture of flocculant Praestol 855BS (50\%) + orange oil $(50 \%)\left[\mathrm{ml} / \mathrm{dm}^{3}\right]$.

The developed equation is appropriate for the following ranges of parameter variability:

$\mathrm{t} \in 1-10$ minutes,

$\mathrm{n} \in 1000-3000$ rotations/minute,

$\mathrm{C}_{\mathrm{F} / \mathrm{O}} \in 0-48 \mathrm{ml} / \mathrm{dm}^{3}$,

hence it can be used by designers within these ranges.

\section{Discussion}

\section{Drainage of municipal wastewater sludge with the use of Flocculant PRAESTOL 855BS}

The first variable parameter with which the water content in the sludge was tested after the process of centrifugal sedimentation was the centrifugation time which was changing within the range from 1 to 10 minutes. The analysis of test results presented in Table 3 and in Figure 1 shows that along with the increase of centrifugation time from 1 to 10 minutes the water content in the sludge may be reduced by $3.49 \%$. The lowest value of water content in the sludge, that is $87.58 \%$, was obtained with centrifugation time equalling 10 minutes. The shape of the curve shows that the biggest drop in the water content in the sludge takes place with the increase of centrifugation time up to five minutes. Further extension of the centrifugation time does not have a significant impact on the drop of water level in the sludge. The decrease of water level in the sludge can be explained by the fact that the time of impact of the centrifugal force is extended along with the rise in centrifugation time (the force acting on the sediment grain in the process of centrifugal sedimentation is definitely the biggest in value), which results in sedimentation and compaction of smaller and smaller sediment grains.

The second variable parameter in the centrifugal sedimentation process was the centrifugation speed which varied within the range from 1000 to 3000 rotations/minute. Test results are presented in Table 4 and Figure 2. The analysis of test results indicates that the increase in rotational speed results in drop of water content in the sludge. Along with the rise in centrifugation speed from 1000 to 3000 rotations/minute the water level in the sludge was dropping by $3.8 \%$. The lowest value of water content in the sludge, that is $89.35 \%$, was obtained with the rotational speed of 3000 rotations/minute. The shape of the curve shows that the biggest drop in water content in the sediment takes place up to about 1500 rotations/minute, from 1500 to 3000 rotations/minute the drop is a little smaller and more or less at the same level. This dependency can be explained by the fact that the centrifugal force which causes filtering off water residues included in the sediment pores increases along with the increase in centrifugal speed.

The next tested variable parameter was the dosage of the solution of flocculant Praestol 855BS with the concentration of $0.3 \%$, which varied within the range from 0 to $48 \mathrm{ml} / \mathrm{dm}^{3}$. The analysis of test results presented in Table 5 and Figure 4 indicates that the increase in the dosage of flocculant Praestol $855 \mathrm{BS}$ has an impact on the drop of water content in the

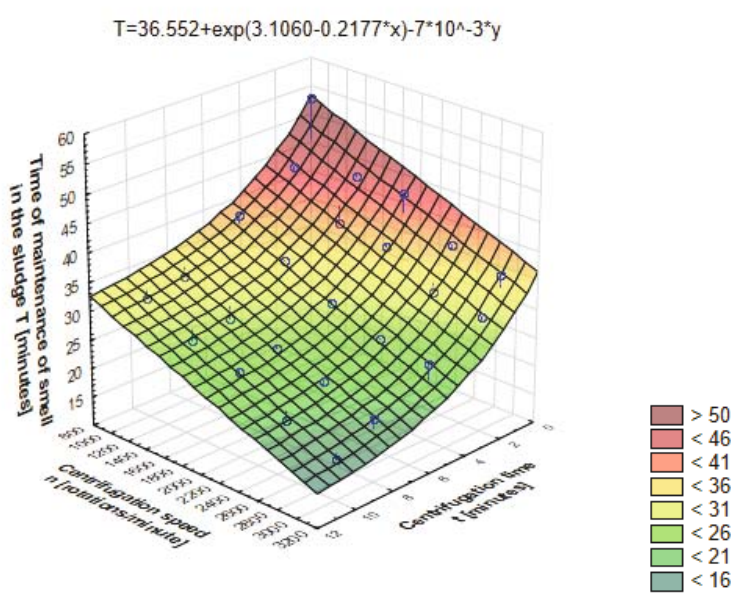

Fig. 19. Diagram of dependency of the time of maintenance of smell $\mathrm{T}$ [minutes] in the function of centrifugation time $t$ [minutes] and centrifugation speed $\mathrm{n}$ [rotations/minute] for a specific dosage of mixture of flocculant $(50 \%)+$ oil $(50 \%)$

$$
\mathrm{C}_{\mathrm{F} / \mathrm{O}}=28 \mathrm{ml} / \mathrm{dm}^{3}
$$

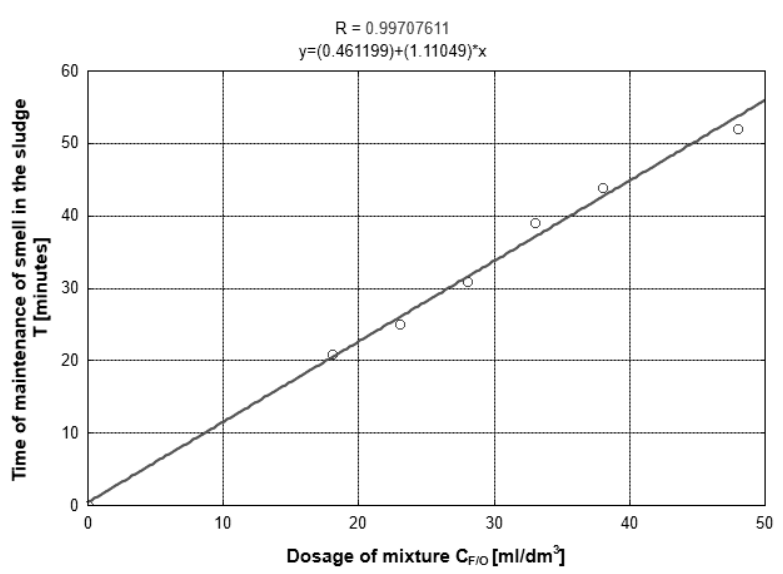

Fig. 20. Impact of dosage of mixture of flocculant (50\%) + oil $(50 \%) \mathrm{C}_{\mathrm{F} / \mathrm{O}}\left[\mathrm{ml} / \mathrm{dm}^{3}\right]$ on time of maintenance of smell in the sludge $T$ [minutes] 
sludge. The bigger the dosage of the flocculant, the smaller the water content in the sediment. Water level in the sludge drops by $2.89 \%$ along with the rise in the dosage of flocculant Praestol $855 \mathrm{BS}$ from 0 to $48 \mathrm{ml} / \mathrm{dm}^{3}$. The shape of the curve indicates that the dosage of flocculant Praestol 855BS of 28 $\mathrm{ml} / \mathrm{dm}^{3}$ is an optimum dosage. Above that the drop of the water content in the sludge is not significant. The flocculant bonds the small colloidal particles of the suspension into bigger agglomerates, that is floccules, which undergo the impact of centrifugal force in a considerably better way due to their bigger mass $\left(\mathrm{m \omega r}^{2}\right)$, thus accelerating the process of centrifugal sedimentation.

The second tested resultant parameter in the process of centrifugal sedimentation was the content of dry mass in the reflux. The test results of the impact of centrifugation time on the content of dry mass in the reflux after the process of centrifugal sedimentation are presented in Table 6 and Figure 5. While analysing test results it can be observed that the rise in centrifugation time causes drop of dry mass content in the reflux. The increase of centrifugation time from 1 to 10 minutes results in drop of dry mass content in the reflux by $349.34 \mathrm{mg} / \mathrm{dm}^{3}$. The lowest value of dry mass in the reflux, that is $1616.22 \mathrm{mg} / \mathrm{dm}^{3}$, was obtained with the centrifugation time equalling 10 minutes. The shape of the curve indicates that further rise of the centrifugation time will result in drop of dry mass content in the reflux, however the drop will not be so clear any more. Hence the time of formation of sedimentation increases along with the rise of centrifugation time, and there is more and more sludge, hence less and less solid particles may permeat to the reflux.

Test results of the impact of rotational speed on the dry mass content in the reflux after centrifugal sedimentation process presented in Table 7 and Figure 6 indicate that the dry mass content in the reflux drops along with the increase of centrifugal speed. Drop of dry mass content in the reflux from $2247.61 \mathrm{mg} / \mathrm{dm}^{3}$ to $1667.76 \mathrm{mg} / \mathrm{dm}^{3}$, that is by $579.85 \mathrm{mg} / \mathrm{dm}^{3}$, was noted along with the increase of centrifugation speed from 1000 to 3000 rotations/minute. The shape of the curve indicates that dry mass content in the reflux quickly drops along with the rise of speed up to 1500 rotations/minute. The increase of speed above 1500 rotations/minute causes a smaller drop. The increase of centrifugal force is caused by the increase of centrifugation speed, hence it forces even the smallest suspension grains to sedimentation, thus removing them from the reflux.

Test results of the impact of the dosage of solution of flocculant Praestol 855BS with the concentration of $0.3 \%$ on the dry mass content in the reflux after centrifugal sedimentation process are presented in Table 8 and Figure 8 . While observing the test results it can be noticed that the increase in the dosage of flocculant Praestol 855BS causes drop of dry mass content in the reflux. The increase in the dosage of flocculant Praestol $855 \mathrm{BS}$ from 0 to $48 \mathrm{ml} / \mathrm{dm}^{3}$ may be obtained by reducing the dry mass content in the reflux by $1928.49 \mathrm{mg} / \mathrm{dm}^{3}$. The lowest value of dry mass content in the reflux, that is $1489.92 \mathrm{mg} / \mathrm{dm}^{3}$, was obtained with the dosage of flocculant Praestol 855BS amounting to $38 \mathrm{ml} / \mathrm{dm}^{3}$. The shape of the curve shows that the dosage of flocculant Praestol 855BS $33 \mathrm{ml} / \mathrm{dm}^{3}$ is the optimum one. Above this dosage the drop of dry mass content in the reflux is small and even results in deterioration of drainage conditions, which can be proved by the increase of dry mass content in the reflux at the dosage of flocculant Praestol 855BS of $48 \mathrm{ml} / \mathrm{dm}^{3}$; probably the viscosity started to have a dominant negative impact along with further increase of the flocculant dosage.

\section{Drainage of municipal wastewater sludge with use of mixture of flocculant PRAESTOL 855BS (50\%) + orange essential oil (50\%)}

The first variable parameter with which the water content in the sludge was tested after the process of centrifugal sedimentation was centrifugation time which was changing within the range from 1 to 10 minutes. The analysis of test results presented in Table 9 and in Figure 9 shows that along with the increase of centrifugation time from 1 to 10 minutes the water content in the sludge may be reduced by $3.46 \%$. The lowest value of water content in the sludge, that is $87.82 \%$, was obtained with centrifugation time equalling 10 minutes. The shape of the curve shows that the biggest drop of water content in the sludge takes place with the increase of centrifugation time up to eight minutes. Further extension of the centrifugation time does not have a significant impact on drop of water content in the sludge.

The second variable parameter in the centrifugal sedimentation process was the centrifugation speed which varied within the range from 1000 to 3000 rotations/minute. Test results are presented in Table 10 and Figure 10. The analysis of results indicates that the increase in rotational speed results in drop of water content in the sludge. Along with the rise in centrifugation speed from 1000 to 3000 rotations/minute water content in the sludge was dropping by $3.51 \%$. The lowest value of water content in the sludge, that is $90.3 \%$, was obtained with the rotational speed of 3000 rotations/minute. The shape of the curve shows that the biggest drop of water content in the sediment takes place up to about 2500 rotations/minute. Further increase in the centrifugation speed does not have a significant impact on drop of water content in the sludge.

The next tested variable parameter was the dosage of the solution of flocculant Praestol 855BS (50\%) + orange oil $(50 \%)$, which varied within the range from 0 to $48 \mathrm{ml} / \mathrm{dm}^{3}$. The analysis of test results presented in Table 11 and Figure 12 indicates that the increase in the dosage of flocculant Praestol $855 \mathrm{BS}(50 \%)+$ orange oil $(50 \%)$ has an impact on the drop of water content in the sludge. Along with the increase in the dosage of mixture of flocculant Praestol 855BS (50\%)+ orange oil (50\%) from 0 to $48 \mathrm{ml} / \mathrm{dm}^{3}$ content of the water in the sludge may be reduced from $92.52 \%$ to $90.08 \%$, that is by $2.44 \%$. The lowest value of water content in the sediment, that is $90.08 \%$ was obtained with the dosage of mixture of flocculant Praestol 855BS (50\%) + orange oil (50\%) of $48 \mathrm{ml} / \mathrm{dm}^{3}$. The shape of the curve indicates that the dosage of mixture of flocculant Praestol 855BS (50\%) + orange oil $(50 \%)$ is optimum. Above that the drop of the water content in the sludge is imperceptible.

The next tested resultant parameter in the process of centrifugal sedimentation was the content of dry mass in the reflux. Test results of the impact of centrifugation time on the content of dry mass in the reflux after the process of centrifugal sedimentation are presented in Table 12 and Figure 13. While analysing the test results it can be observed that the rise in centrifugation time causes drop of dry mass content 
in the reflux. An increase of centrifugation time from 1 to 10 minutes results in drop of dry mass content in the reflux by $331.83 \mathrm{mg} / \mathrm{dm}^{3}$. The lowest value of dry mass in the reflux, that $1972.39 \mathrm{mg} / \mathrm{dm}^{3}$, was obtained with the centrifugation time of 10 minutes. The shape of the curve indicates that along with the rise of centrifugation time up to 5 minutes the dry mass content in the reflux drops quickly, while above 5 minutes the drop is much smaller.

On the basis of the test results of the impact of rotational speed on the dry mass content in the reflux after centrifugal sedimentation process presented in Table 13 and Figure 14 it can be stated that dry mass content in the reflux drops along with the increase of centrifugal speed. Drop of dry mass content in the reflux from $4079.23 \mathrm{mg} / \mathrm{dm}^{3}$ to $2125.26 \mathrm{mg} / \mathrm{dm}^{3}$, that is by $1953.97 \mathrm{mg} / \mathrm{dm}^{3}$, was noted along with the increase of centrifugation speed from 1000 to 3000 rotations/minute. The shape of the curve indicates that the biggest drop of dry mass content in the reflux takes place up to about 2000 rotations/minute, while it is much smaller above 2000 rotations/minute.

Test results of the impact of the dosage of mixture of flocculant Praestol 855BS (50\%) + orange oil $(50 \%)$ on the dry mass content in the reflux after centrifugal sedimentation process are presented in Table 14 and Figure 16. While observing the test results it can be noticed that the increase in the dosage of mixture of flocculant Praestol 855BS (50\%) + orange oil $(50 \%)$ causes drop of dry mass content in the reflux. The increase in the dosage of mixture of flocculant Praestol 855BS (50\%) + orange oil (50\%) from 0 to $48 \mathrm{ml} / \mathrm{dm}^{3}$ may be obtained by reducing the dry mass content in the reflux by $1592.33 \mathrm{mg} / \mathrm{dm}^{3}$. The lowest value of dry mass content in the reflux, that is $1932.75 \mathrm{mg} / \mathrm{dm}^{3}$, was obtained with the dosage of mixture of flocculant Praestol 855BS $(50 \%)+$ orange oil $(50 \%)$ amounting to $18 \mathrm{ml} / \mathrm{dm}^{3}$, from $18 \mathrm{ml} / \mathrm{dm}^{3}$ to $33 \mathrm{ml} / \mathrm{dm}^{3}$ the drop is much smaller, while above $33 \mathrm{ml} / \mathrm{dm}^{3}$ the dry mass content in the reflux drops. It can be noted that the dosage of mixture of flocculant Praestol 855BS (50\%) + orange oil $(50 \%)$ is still not the optimum dosage and its further increase will allow to reduce the dry mass content in the reflux.

The last tested resultant parameter in the centrifugal sedimentation process was the time of maintenance of smell in the sludge. Test results of the impact of centrifugation time on the time of maintenance of orange oil smell in the sludge after centrifugal sedimentation process which are presented in Table 15 and Figure 17 show that the time of maintenance of the essential oil smell in the sludge drops along with the increase of centrifugation time. The rise of centrifugation time from 1 to 10 minutes resulted in the drop in time of maintenance of smell in the sludge by 18 minutes. The lowest value, that is 20 minutes, was obtained with centrifugation time of 10 minutes. The shape of this curve indicates that further increase in centrifugation time will result in drop in time of maintenance of the oil's smell in the sludge. The drop in time of maintenance of the smell in the sludge may be explained by the fact that longer centrifugation time results in longer time of impact of centrifugal force on the drained sludge, which displaces both water and oil particles from the sedimented sludge, causing bigger oil volume to permeat to the reflux. The fact that oil density is smaller than water density shall also be considered, as it results in the oil floating on the reflux surface.
Test results of the impact of rotational speed on the time of maintenance of orange essential oil in the sludge after the centrifugal sedimentation process are presented in Table 16 and Figure 18. The analysis of the test results indicates that the increase of centrifugation speed results in the drop in time of maintenance of smell in the sludge. The increase of centrifugation speed from 1000 to 3000 rotations/minute resulted in drop in time of maintenance of smell in the sludge by 14 minutes. The lowest value of time of maintenance of smell in the sludge, that is 30 minutes, was obtained at centrifugation speed of 3000 rotations/minute. The shape of the curve shows that the increase in centrifugation speed will also cause further drop in time of maintenance of the oil's smell in the sludge. The drop in time of maintenance of smell in the sludge may be explained by the fact that the centrifugal force which displaces oil and water particles from the sedimented sludge increases along with the rise of centrifugation speed, resulting in bigger oil volume permeating to the reflux. In this case oil density shall be considered, which is smaller than water density and floats on the reflux surface under the impact of centrifugal force.

Test results of the impact of mixture of flocculant Praestol $855 \mathrm{BS}(50 \%)+$ orange oil $(50 \%)$ for the time of maintenance of orange oil smell in the sludge after centrifugal sedimentation process are presented in Table 17 and Figure 20. While observing the test results it can be noted that the increase in the dosage of mixture of flocculant Praestol 855BS $(50 \%)+$ orange oil $(50 \%)$ results in the increase in the time of maintenance of the smell in the sludge. The highest value of time of maintenance of smell in the sediment, that is 52 minutes, was obtained with the dosage of mixture of flocculant Praestol 855BS (50\%) + orange oil (50\%) amounting to $48 \mathrm{ml} / \mathrm{dm}^{3}$. The shape of this curve indicates that increasing the dosage of mixture of flocculant Praestol 855BS (50\%) + orange oil (50\%) will result in the increase in time of maintenance of the oil's smell in the sludge. This can be explained by the fact that the oil volume in the drained sludge increases along with the increase of the dosage, thus the time of efficient neutralization of unpleasant smells in the sludge increases.

After the introduction of orange essential oil to the wastewater sludge, the unpleasant smell of the sludge was mitigated or disappeared. This was due to the compounds belonging to the group of terpenes, among others limonene and neroli, which constitute a part of the composition of orange essential oil. These compounds have the highest thresholds of olfactory sensitivity and they determine the characteristic smell of orange essential oil.

The mechanism of smell neutralization has not been explained yet. In this case the simplest explanation is that part of the receptors of olfactory epithelium were blocked by the compounds defining the characteristic smell of orange essential oil, which contributed to change in the character of smell of drained sludge from unpleasant to pleasant, in which the smell of orange essential oil was perceptible.

\section{Conclusions}

- The orange essential oil has an impact on drop of resultant quality parameters of the drainage process of municipal wastewater sludge (water content in the sludge and dry mass content in the reflux). 
- A slightly better quality of drainage of wastewater sludge is obtained with the use of flocculant Praestol 855BS compared to mixture of flocculant Praestol $855 \mathrm{BS}(50 \%)+$ orange essential oil $(50 \%)$ (difference of water content in the sludge amounts to barely $0.54 \%$, while in the case of dry mass content in the reflux to $918 \mathrm{mg} / \mathrm{dm}^{3}$ ).

- A slightly higher water content in the sludge and higher dry mass content in the reflux is technologically acceptable.

- Dosing orange essential oil has an impact on considerable reduction of odours giving off from the drained wastewater sludge, thus on the improvement of work conditions connected with operation of centrifugal separators.

- On the basis of the conducted tests and bearing in mind both the effective process of drainage of wastewater sludge and simultaneous reduction of unpleasant smells exuding from the sludge during this process it is assumed and recommended to simultaneously apply and dose two reagents, that is flocculant Praestol 855BS (50\%) and orange essential oil, also in the volume of $50 \%$.

\section{References}

ASHLAND Material Safety Data Sheet of flocculant PRAESTOL 855BS, sheet number: R030840. (in Polish)

Brudniak, A., Dębowski, M. \& Zieliński, M. (2013). Determination of the odorous influence of selected wastewater treatment plant on area covered by elaboration of spatial development plan, Annual Set The Environment Protection, 15, 2, pp.1759-1771. (in Polish)

Brudniak, A., Dębowski, M., Zieliński, M., Brudniak, A. \& Niedźwiecka, K. (2014). Analysis and identification of causes of odour nuisance of wastewater management facilities (WMF) for Olsztyn, in: Interdisciplinary Issues in Environmental Engineering, Traczewska, T.M. \& Kaźmierczak, B. (Eds.), 4, Publishing House of Wrocław University of Technology, Wrocław 2014, pp. 109-120. (in Polish)

Czerwiński, J. \& Ozonek, J. (2008). Elimination of odorous in off-gases from food production by means of ozone, Chemical Engineering Transactions, 15, pp. 177-182.

Dębowski, M., Zieliński, M., Krzemieniewski, M. \& Białowiec, A. (2008). Fenton reaction influence on the reduction of $\mathrm{H}_{2} \mathrm{~S}$ generated and putrefaction of municipal wastewater, Annual Set The Environment Protection, 10, pp. 289-300. (in Polish)

Kośmider, J. \& Krajewska, B. (2007). Determining temporary odour concentration under field conditions - Comparison of methods, Polish Journal of Environmental Studies, 16, 2, pp. 215-225.

Kośmider, J. (1994). Odour nuisance. Classification of areas and sources of air pollution emmisions, Archives of Environmental Protection, 1-2, pp. 31-41. (in Polish)

Kośmider, J. (2007). Measurements of odour concentration - dynamic olfactometry, Water-Sewage, 10, pp. 34-35. (in Polish)

Kośmider, J., Mazur-Chrzanowska, B. \& Wyszyński, B. (2012). Odours, Polish Scientific Publishing, Warszawa 2012. (in Polish)

Kowalczyk, A. \& Piecuch, T. (2011). Application of essential oil from orange for masking of unpleasant odours generated during dewatering of municipal sewage sludge, Ecological Engineering, 25, pp. 124-134. (in Polish)
Kowalczyk, A., Kutryn, J. \& Piecuch, T. (2010). Neutralization of odours arising during dewatering of municipal sewage sludge in the process of centrifugal sedimentation, Annual Set The Environment Protection, 12, pp. 365-380. (in Polish)

Kowalczyk, A., Piecuch, T. \& Andriyevska, L. (2013). The use of pine essential oil for masking the odours emitted in the process of mechanical dewatering of municipal sewage sludge, Annual Set The Environment Protection, 15, 1, pp. 807-822. (in Polish)

Kujawa-Roeleveld, K. \& Michałkiewicz, M. (2011). Air pollution around the wastewater treatment plant, in: Tutorial for the operator of the wastewater treatment plant, Dymaczewski, Z. (Ed.), Polish Association of Sanitary Engineers and Technicians, Poznań 2011, pp. 413-467. (in Polish)

Kulig, A. (2005) Sources and impact of the odorants emitted from wastewater treatment facilities, Communal Review, Communal Notebooks, 11, pp. 99-103. (in Polish)

Kulig, A., Lelicińska-Serafin, K., Podedworna, J., Sinicyn, G., Heidrich, Z. \& Czyżkowski, B. (2010). Identification, inventory and characterization of odorant sources in municipal management in Poland, in: Contemporary problems of odours, Szynkowska, M. \& Zwoździak, J. (Eds.), Scientific and Technical Publishing, Warszawa 2010, pp. 14-53. (in Polish)

Ozonek, J., Jahołkowski, K. \& Czerwiński, J. (2009). The limitation of odour nuisance in animal waste treatment plants, Chemical Industry, 88, 5, pp. 544-547. (in Polish)

Ozonek, J., Szulżyk-Cieplak, J. \& Czerwiński, J. (2009). Reduction of odour emission from wastewater from sugar industry with application of hydrodynamic cavitation, Annual Set The Environment Protection, 11, pp. 1054-1062. (in Polish)

Piecuch, T., Kowalczyk, A., Dąbrowski, T., Dąbrowski, J. \& Andriyevska, L. (2015). Reduction of odorous noxiousness of sewage treatment plant in Tychowo, Annual Set The Environment Protection, 17, pp. 646-663. (in Polish)

Piecuch, T., Kowalczyk, A., Kupś, D. \& Gomółka, D. (2011). Method of neutralization of odours arising during mechanical dewatering of municipal sewage sludge, Annual Set The Environment Protection, 13, pp. 747-768. (in Polish)

Sówka, I. (2011). Methods of identification of odour gases emitted from industrial plants, Monographs No. 55, Publishing House of Wrocław University of Technology, Wrocław 2011. (in Polish)

Sówka, I., Kita, U., Skrętowicz, M., Nych, A. \& Zwoździak, J. (2013). The conditions and requirements necessary for the proper functioning of the olfactometric laboratory, Annual Set The Environment Protection, 15, 2, pp. 1207-1215. (in Polish)

Sówka, I., Nych, A. \& Zwoździak, J. (2011). Application of German solutions in odour annoyance evaluation in Poland, Annual Set The Environment Protection, 13, pp. 1275-1288. (in Polish)

Szklarczyk, M., Zwoździak, J. \& Sówka, I. (2010). Industrial sources of odours emission, in: Contemporary problems of odours, Szynkowska, M. \& Zwoździak, J. (Eds.), Scientific and Technical Publishing, Warszawa 2010, pp. 54-85. (in Polish)

Szynkowska, M., Wojciechowska, E., Węglińska, A. \& Paryjczak, T. (2009). Odours. Current problem in environment protection, Chemical Industry, 88, 6, pp. 712-720. (in Polish)

Szynkowska, M., Wojciechowska, E., Węglińska, A. \& Paryjczak, T. (2008). Catalysts used in oxidation of odorous, Chemical Industry, 87, 8, pp. 834-843. (in Polish) 


\section{Odwadnianie osadów ściekowych w wirówce dekantacyjnej wspomagane flokulantem kationowym Praestol 855BS i olejkiem eterycznym z odpadu skórek pomarańczy}

Streszczenie: W pracy przeprowadzono ocenę porównawczą wyników badań odwadniania komunalnych osadów ściekowych z zastosowaniem flokulanta Praestol 855BS i mieszaniny flokulant Praestol 855BS 50\% + olejek eteryczny z pomarańczy $50 \%$, jako odczynników wspomagających ten proces, a także podjęto próbę obniżenia nieprzyjemnych zapachów wydzielających się z odwodnionych osadów. Proces odwadniania komunalnych osadów ściekowych prowadzono w laboratoryjnej wirówce sedymentacyjnej typu MPW-350. Parametrami zmiennymi niezależnymi procesu odwadniania były czas wirowania, prędkość wirowania, dawka flokulanta Praestol 855BS oraz dawka mieszaniny w proporcji flokulant Praestol 855BS 50\% + olejek eteryczny z pomarańczy 50\%. Ocenie poddano: zawartość wody w osadzie, zawartość suchej masy w odcieku oraz czas utrzymywania się zapachu olejku w osadzie. Przeprowadzone badania wykazały, że olejek eteryczny z pomarańczy wpływa na spadek parametrów wynikowych, jakościowych procesu odwadniania komunalnych osadów ściekowych. Dozowanie olejku eterycznego z pomarańczy wpływa na znaczne obniżenie odorów wydzielających się z odwodnionych osadów ściekowych, a tym samym na polepszenie warunków pracy obsługi wirówek. Mając na uwadze zarówno efektywny proces odwadniania osadów ściekowych z jednoczesnym zmniejszeniem nieprzyjemnych zapachów wydzielających się z osadów podczas tego procesu, przyjmuje się i zaleca do aplikacji dawkowanie jednoczesne obydwu odczynników, tj. flokulanta Praestol 855BS 50\% oraz olejku eterycznego z pomarańczy także 50\% udziału objętościowego. 